\title{
THE IMPACT OF WARRANT INTRODUCTION: AUSTRALIAN EXPERIENCE
}

\author{
Michael Clarke \\ Gerard Gannon* \\ Russell Vinning \\ School of Accounting, Economics and Finance \\ Faculty of Business and law \\ Deakin University \\ Victoria, 3125 \\ Australia \\ Email: gerard@deakin.edu.au \\ Fax: (61 3) 92446283
}

Phone: (61 3) 92446243

\begin{abstract}
The impact that derivative trading has on the underlying security is essential to our understanding of security market behaviour, and important in the fields of market efficiency and pricing of such derivatives. This paper examines the impact that the introduction of exchange traded derivative warrants has on the underlying securities' price, volume and volatility in the Australian market. The major findings of significant negative abnormal returns, reduction in skewness, no change in beta and small changes in variance are consistent with recent research findings in the US, UK and Hong Kong. However findings of derivative warrant listing resulting in decreased trading volume in contrast with most prior research in the field.
\end{abstract}

* Corresponding Author

PRELIMINARY FINAL DRAFT: Feb 2005

Keywords: Derivatives, Warrants, Market Efficiency, Event Study.

JEL Classification: 


\begin{abstract}
The impact that derivative trading has on the underlying security is essential to our understanding of security market behaviour, and important in the fields of market efficiency and pricing of such derivatives. This paper examines the impact that the introduction of exchange traded derivative warrants has on the underlying securities' price, volume and volatility in the Australian market. The major findings of significant negative abnormal returns, reduction in skewness, no change in beta and small changes in variance are consistent with recent research findings in the US, UK and Hong Kong. However findings of derivative warrant listing resulting in decreased trading volume in contrast with most prior research in the field.
\end{abstract}

* Corresponding Author

PRELIMINARY FINAL DRAFT: Feb 2005

Keywords: Derivatives, Warrants, Market Efficiency, Event Study.

JEL Classification: 


\section{INTRODUCTION}

The major purpose of this study is to examine the impact issuance of derivative warrants has on the underlying securities' price in the Australian stock market. The impact warrant introduction has on volume and risk of the underlying securities is also examined. This section commences with an overview of the warrants market in Australia, followed by a brief review of related research, a summary of the methodology used, and concludes with a discussion of applications and the importance of the research area.

An exchange traded derivative warrant (hereafter simply referred to as a warrant) in the Australian market is different in form to the common financing warrants present in other capital markets. The Australian warrant is essentially the same as a stock option - they give the holder the right, but not the obligation to exercise the warrant to gain a position in the underlying security. Unlike financing warrants, they are not issued by the company itself, but by a third party, such as an investment bank ${ }^{1}$, and also unlike financing warrants do not involve the creation of new securities when exercised.

The Australian warrant market is run as a public exchange, administered by the Australian Stock Exchange Ltd (ASX). Incidentally, the ASX also administers the exchange traded stock options market in Australia, which represents competition to the warrants market as similar products are offered. Between 1997 and 2002, there have been (or still are), 145 listed companies with traded warrants available, compared to only 51 listed companies with traded options available. As shown in Figure 1, the warrants market was quite small prior to 1996/97, but has since experienced dynamic growth and innovation, with new products continually being developed and offered. As reported in the ASX FactFile 2003, the warrants market has grown approximately 12 times over (1200\%) since 1997, while the options market has grown approximately $28 \%$ over the same period ${ }^{2}$, suggesting participants are possibly substituting options for warrants. This suggests that the warrants market plays a relatively more important role than the options market

\footnotetext{
${ }^{1}$ See Appendix A for an overview of the major warrant issuers and there relative importance in the warrant market. ${ }^{2}$ Figures calculated from data presented in the ASX FactFile 2003. Unfortunately we were not able to obtain from the ASX, data that provides a direct comparison for trading volume between the markets, value of contracts or value of underlying assets, which allow better comparisons. Nonetheless, it can be seen from the publicly available data the relative importance of the two markets.
} 
in Australian finance. This is a major reason why the research into the interactions such products have with the underlying security is important.

Figure 1: Growth of the Derivative Warrants Market 1996 - 2003

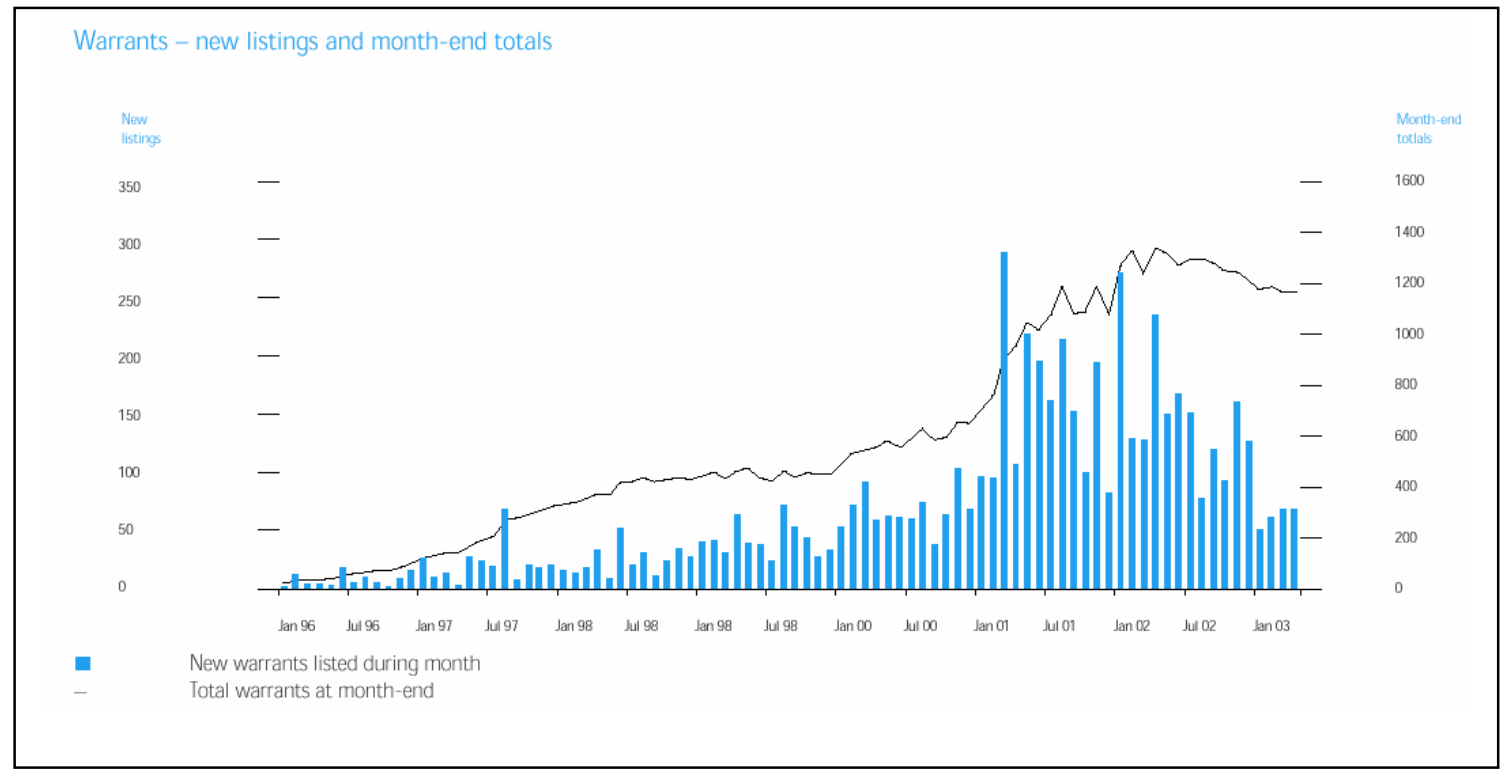

Source: ASX Yearbook 2003

The ASX has two general classes of warrants. Short term, speculative style warrants are termed Trading Warrants, while longer term warrants are termed Investment Warrants. Trading warrants include Call Warrants, Put Warrants, Barrier Call Warrants and Capped Warrants, while Investment Warrants include Instalment Warrants, PIE (Premium Income Endowment) Warrants and HOTS ${ }^{3}$ Warrants.

For the purpose of this research, the important point to note is that warrants are similar to exchange traded options. Warrants (and options) offer an investor/trader a differential opportunity set of risk/return payoffs than are possible in the underlying security only. Warrants (and options) give the investor a leveraged position in the underlying security. The biggest difference between exchange traded options and warrants is the counter-party risk. The options market eliminates the counter-party risk through margining and the clearing house ${ }^{4}$, while

\footnotetext{
3 "HOTS" is not an acronym, though the warrants are sometimes called "High Octane" in reference to their leverage. The name HOTS is merely a title given to assist marketing.

${ }^{4}$ While there is always the risk the clearing house will default, such mechanisms are generally considered to eliminate counter-party risks. To this author's knowledge, no major clearing house has ever defaulted.
} 
warrants are issued by a bank or investment bank who guarantees payment. The purchaser of the warrant thus bears counterparty risk if the issuer of the warrant defaults. Another difference is that some types of warrants, eg instalments, may have an extended life of up to 10 years, while options are generally illiquid (or unavailable) beyond two years. Apart from Put warrants, all the other warrants are profitable to the investor (thus unprofitable to the issuer) when the stock price increases (and vice versa). Unlike the options market, there is no designated market maker ensuring liquidity; however in practice the issuer will generally act in the role of market maker. As mentioned previously, both the warrant and options markets are administrated by the ASX, however the warrant market uses the same trading and clearing house systems as the stock market (SEATS and CHESS), while the options market uses different trading and clearing systems (DTS and OCH). Many Australian online on-line brokerages ${ }^{5}$ offer trading access to the warrant market, but no or limited access to the options market.

The majority of previous research in the field of derivative impacts on the underlying stock is based on option introduction, with limited research also available on futures introduction. However, despite the theories developed to explain the impact derivative trading has on the underlying stock based on option introduction, Australian warrants and options share sufficiently similar characteristics, i.e. differential payoff patterns and leverage, for the theories to still apply. Ross (1976) was the first theorist to suggest that option introduction would have an impact on the underlying stock price. This was despite traditional option pricing methodologies, (eg Black \& Scholes, 1977) which rely on arbitrage conditions. Arbitrage conditions implicitly assume that the option is a redundant security and therefore should have no impact on the underlying security.

Ross (1976), Miller (1977), DeTemple \& Seldon (1991) and Figlewski \& Webb (1993) all provide frameworks for explaining the impact option listing on the underlying security price and other characteristics. However, to date empirical research has failed to verify singularly any of the hypotheses. Generally the conceptual frameworks for understanding the impact that derivative option introduction has on the underlying security can be termed the Complete

\footnotetext{
${ }^{5}$ For example e-trade (www.etrade.com.au $)$ and Comsec (www.comsec.com.au), who are two of the more popular online trading sites.
} 
Markets hypothesis, the Diminishing Short-Sales Restrictions hypothesis and the Improved Information Environment hypothesis ${ }^{6}$.

The complete markets theory of Ross (1976) and Arditti \& John (1980) states that introduction of options expands the opportunity set of risk/return patterns available to investors, allowing more optimal/desirable positions than possible in a market absent of options. This creates increased demand for the securities, as some investors are induced to trade by the improved opportunity set, resulting in higher equilibrium prices.

The diminishing short sales theory suggests that completing the market by introducing options allows for the creation of a synthetic short position ${ }^{7}$, allowing pessimistic investors with a negative view on the stock to trade on their information, whereas previously the rules restricting short-sales ${ }^{8}$ may not have allowed them to. Miller (1977) contends that short-sale constraints restrict informational efficiency, with negative information unable to be impounded into the price. Thus, only optimistic investors purchase the security, creating a supply-demand imbalance resulting in higher equilibrium prices. The argument is that with the ability to create synthetic short positions in the options market, the supply-demand imbalances are corrected through arbitrage, leading to lower equilibrium prices.

The improved information environment hypothesis has many facets and is not presented as a single clear statement by theorists. However, elements of the improved information environment hypothesis support the reduction in short-sales hypothesis, as it suggests informed traders with negative information can now trade and profit from their superior information sets. Another facet includes predicting an increase in analyst and media coverage following derivative introduction and changes in the mix of insider/speculative/uninformed investors in the underlying stock.

\footnotetext{
${ }^{6}$ While "Complete Markets" and "Diminishing Short Sales Restrictions" are commonly used terms throughout the literature, "Improved Information Environment" is not. Sometimes referred to as the Informed Trading hypothesis, this author considers the title used here to more accurately reflect the different theories, as the informed trading aspect is a narrow focus of the overall information environment theory.

${ }^{7}$ A synthetic short position consists of buying a put and writing a call. This creates the same payoff as a short position in the stock.

${ }^{8}$ Some of the rules restricting short selling on the NYSE include only being able to short sell on an up-tick. In addition, many brokers only allow trusted long term clients to short sell and often do not allow clients access to the full proceeds of the short sale, reducing the incentives to short-sell and thus the informational efficiency of the market. Similar structures apply in Australia.
} 
In this research we are testing the impact of first time warrant issue, for each type of warrant traded on individual securities. Warrant data is obtained for the ASX for all first time warrant issues between 1997 and 2003, while Almax Information Systems provides companies stock price data over the same period.

This research adopts standard event study abnormal return methodology, and is largely based on the foundations set in Brown \& Warner (1985) and MacKinley (1997). Other methodologies, such as GARCH analysis of variance changes and dummy variable regressions to test for beta change, will be used in conjunction with the abnormal return methodology to provide robustness to the findings. While we test numerous characteristics, the impact warrant introduction has on the stock price is considered the most important.

Investigating the impact of an event is a very common theme in research in financial economics. The methodology has been used to investigate the impact of earnings announcements (eg Ball \& Brown, 1976), macro-economic events (eg Singh, 1995) and capitalisation changes (eg Ikenberry, Lakonishok and Vermaelen, 1995) to name just a few. The research into the field of exchange traded options has been extensive, and several methodologies are used. Event study methodology has enjoyed widespread use due to ease of application, in addition to its ability to find abnormal effects using small data sets without losing any relative power. Brailsford (1997, p478) states that "(event studies are) ... generally regarded as an extremely powerful methodology", while Fama (1991, p1602) states “... it is important to emphasise the main point. Event studies are the cleanest evidence we have on market efficiency." However, it is recognised that event study approaches are sensitive to selection of event dates and results may be influenced by multiple events occurring around the same time.

The most common methodology, and the methodology adopted in this research, is to calculate abnormal returns (i.e. daily return over-and-above the return expected if the event had not occurred) and test whether these returns are statistically significant. To test the impact of warrant introduction on volume, variance and beta measures, dummy variable regression techniques are used.

The dataset and methodology are presented and discussed in greater detail throughout section 3 . 
There is a dearth of research into the operations of the Australian derivative markets. Due to the small size and relative youth of the Australian market, researchers have generally neglected it ${ }^{9}$. However, the Australian financial markets, especially in the area of exchange traded derivative products, are very innovative. For example, the Sydney Futures Exchange (SFE) was the first major exchange in the world to trade Individual Stock Futures (ISF), when they listed in May 1994. The warrants market in Australia is also a leader in innovation of exchange traded financial derivatives, with products such as instalments, barrier calls and PIE's on individual stocks not being exchange traded on any other major exchange.

Therefore, the Australian financial markets can clearly be seen as innovators in the area of exchange traded derivatives. ISF's (called Single Stock Futures (SSF) in the USA) are now common across major economies, and are considered on one of the biggest advances within their financial markets in recent times ${ }^{10}$. The success the derivative warrants have enjoyed in Australia, as evidenced in section 1, would suggest that such products will eventually become exchange traded in other capital markets. An examination of listing impacts such products have on the Australia market may lead to an indicator of their impacts on other markets.

This paper is a preliminary, exploratory study into a market that has been neglected in financial economic research. As demonstrated throughout the literature review in section 2, empirical evidence is mixed regarding the impact of derivative introduction. As such, it is important to examine the Australian market to determine exactly what the impacts are. Due to the complex nature of the warrants market in Australia, it is hoped that this paper will encourage further research into the interactions such products have with the underlying security.

This section has served as an overview of the derivative warrants market in Australia and the broad research area. Section 2 reviews the relevant theoretical frameworks developed by theorists and compares and analyses empirical results and how they fit within the theoretical frameworks. Section 3 describes the data collection and filtering process as well as the methodology adopted. Section 4 presents empirical findings regarding price, volume and risk. Section 5 discuss the results in context of the theoretical frameworks, and compares and

\footnotetext{
${ }^{9}$ There are insolated cases of research, for example, Brailsford, Faff and McKensie (2001), who examine the impact of Individual Stock Futures.

${ }^{10}$ Partnoy (2001) provides an overview of the debate surrounding SSF's in the USA, especially in regards to regulatory implications.
} 
contrasts with previous findings in other markets. Section 6 summarises conclusions drawn and suggested avenues of future research in the field. 


\section{LITERATURE REVIEW}

The majority of research in the area of the effects of derivative issuance and trading has used data from US option and stock markets, such as Chicago Board Options Exchange (CBOE) and American Stock Exchange (AMEX). Many studies have been conducted using older pre-90's data (eg Conrad, 1989). However the topic has again provoked interest from researchers, with new research showing that the conclusions drawn from earlier research may not be as robust as first thought. The new interest in the topic can be attributable to the massive growth in the derivative markets over the last $\operatorname{decade}^{11}$, as well as new empirical techniques developed ${ }^{12}$. Recent studies have branched away from US data, with research being published ON the UK (eg Watt, Yadav \& Draper, 1993) and Hong Kong (eg Chen \& Wu, 2000) markets. The literature review will first discuss the frameworks and theoretical explanations for changes in stocks following option introduction, followed by discussions of empirical findings regarding price, volume, risk and other factors, and will conclude with a summary of relevant findings and implications for the theoretical frameworks.

Traditional option pricing models, such as Black and Scholes (1973), use arbitrage to price derivatives. Under arbitrage assumptions, the derivative product can be replicated through using other available products ${ }^{13}$, thus regarding the option as a redundant security. If the option is a redundant security, the introduction of the option contract should not cause any effects in the underlying stock market. However, theoretical and empirical research has shown this is not the case. Three general theories have been developed to predict and explain these effects, sometimes contradicting each other. These theories are referred to here as Complete Markets, Diminishing Short Sales Restrictions and Improved Information Environment theorems.

The complete markets theory, as applied to options, began with Ross (1976) and is continued in Ardetti \& John (1980). Ross (1976) constructs a state-space framework which shows that introducing call and put options (either or both) significantly increases the state-space of

\footnotetext{
${ }^{11}$ Greenspan (1999) states derivative use had grown to an estimated \$33USD trillion in notional value, at a compound rate of over 20\% per year over the preceding decade (1989-1999).

${ }^{12}$ An example of a new empirical technique being used is the application of GARCH methodology to determine whether conditional variance (volatility) of the stock changes. Research by Draper, Mak and Tang (2001) and Faff and Hillier (2003) has used this methodology.

${ }^{13}$ Black and Scholes (1973) assume that a call option can be replicated through a dynamic portfolio of risk free bonds and long/short positions in a stock.
} 
potential investor returns. He uses this framework to show that introducing such products, which have differential pay-offs to those available in trading a stock alone, increases market efficiency. The increase in market efficiency is attributed to the ability of investors with differential preference sets to enter the market ${ }^{14}$. The end result is greater liquidity, higher equilibrium prices and decreased volatility. Early empirical findings, such as Conrad (1989) and DeTemple \& Jorian (1990), supports the complete markets theory.

As mentioned previously, the diminishing short sales restriction theory is a branch of the complete markets theory. Miller (1977) and Diamond \& Verrecchia (1987) argue that restrictions in short-sales lead to higher and more volatile prices in the underlying security. For instance, where investors have differing views on the value of the stock, only optimistic investors can trade on their opinion/information set, creating a supply demand imbalance in the security ${ }^{15}$. Options give an avenue to incorporate the negative information that is unavailable when shortsales are restricted through writing a call or purchasing a put. Arbitrage conditions between the stock and options prices will result in lowering equilibrium stock prices and volatility. Under Miller's (1977) arguments, one can conclude that introducing options will lead to lower prices, lower volatility and increased market efficiency. Recent empirical research, such as Danielson \& Sorescu (2001), supports the diminishing short-sales restrictions theory.

Figlewski \& Webb (1993) also argue that when short-sales are restricted and expensive efficiency can only be achieved through an options market. When an investor has negative information they will purchase a put, which will then indirectly lead to a short-sale in the spot market. The seller (writer) of the put will short the stock to hedge their position. As the writer is most likely a specified professional market maker, they face the least costs and restrictions regarding short-selling. The short-selling pressure will lead to decreased prices to maintain supply-demand equilibrium. The end result is increased transactional (lowest cost) and

\footnotetext{
${ }^{14}$ Without options, the only potential pay-off patterns are either long or short in the underlying security. Investors who are not satisfied with either of these positions will not enter the market. Introducing options creates a new set of potential strategies (with different risk/reward functions). Examples of strategies available with options, but unavailable in the underlying security, are Protective Put, Straddles, Strangles, Strips, Straps or Calendar Spreads to name a few. See Saliba (2002) for a description of these and other option strategies.

${ }^{15}$ Millers (1977) argument can be extended to the pricing of the options themselves. Under the Black-Scholes model, the call prices are higher under high stock price and higher with greater volatility. This creates incentive to write over-valued call options, thus helping correct the supply-demand imbalances. Unfortunately, the higher volatility will mean put options are also overpriced, resulting in less incentive to purchase a put and create a full synthetic short position, therefore predicting that while the stock price will adjust downwards, it will still be overvalued. Miller (1977) does not recognize this or what impact it may have on his final conclusions.
} 
informational (negative information being incorporated) efficiency in the combined stock and options market. Under this framework, opening an options market will lead to an increase in the transactional and informational efficiencies of the stock market.

Under pricing models, put-call parity and complete markets, the put option ${ }^{16}$ is a redundant security that can be replicated through the use of two other securities, short in the stock and long in the call. Grossman (1988) notes that in all cases in the US, calls were introduced either prior to or at the same time as puts, fulfilling the necessary conditions for put-call parity arbitrage. However, due to restrictions on use of proceeds from short-sales and the multiple transaction costs involved, Grossman (1988) argues that the put is not a redundant security.

As mentioned previously, the improved information environment hypothesis consists of a series of sub-hypotheses, regarding the information environment of the underlying security. As the subsequent discussion notes, introducing options may improve the information environment of the security for various reasons. Throughout the finance literature (eg, Lang, Lins \& Miller, 2003 ) better information environments are generally associated with higher market valuations ${ }^{17}$.

The first sub-hypothesis of the improved information environment is concerned with informed traders. The option market offers an attractive market to informed traders ${ }^{18}$. With transaction costs that are typically lower, less regulatory scrutiny of actions and high leverage, it is argued that informed traders have incentives to shift their participation away from the stock market to the options market. This theory leads to an expected decrease in volume in the underlying security, and an expectation that option prices will contain information not yet incorporated into stock prices, i.e. the option market will become more informationally efficient than the underlying stock market.

Another branch of the improved information environment theory suggests that introducing options increases media coverage, analyst coverage and investor awareness. This increased interest in the security will lead to increased liquidity and more accurate forecasts. Under this

\footnotetext{
${ }^{16}$ As previously mentioned, the call is also a redundant security under arbitrage free pricing models. The put is even easier to arbitrage through put-call parity pricing assumptions, if the call is in existence prior to the put. ${ }^{17}$ This may be due to more positive information being known by investors; however the "new" improved information is as likely to be negative as positive by definition (ignoring companies signaling motivations). It is more logical, and consistent with asset pricing theory, to assume that investors use a discount rate to price the security. Included in this discount rate is a "risk premium" for poor information environments, which decreases under better information environments. As the discount rate decreases, market valuation will increase, ceteris paribus.

${ }^{18}$ Informed traders are defined here as insiders (eg managers) or those with superior information sets (eg good analysts)
} 
hypothesis, smaller firms stock prices will experience greater impacts than larger firms stock prices. This is due to larger firms already having relatively strong information environments, with many analysts and extensive news coverage. Any increase in analyst coverage for small firms following option introduction will be proportionally greater than that for large firms ${ }^{19}$.

The financial press (eg Warde, 1998) has often expressed that derivatives are de-stabilising due to their complex nature and they encourage a gamblers attitude towards capital allocation. This has been fuelled by public conception surrounding high profile collapses involving derivative products such as Baring Brothers, Long Term Capital Management and Orange County. In contrast though, theoretical frameworks and empirical evidence find that derivatives actually reduce the volatility of the underlying security. Faff and Hillier (2003) suggest that due to leverage and transaction cost differentials, speculators have an incentive to shift their "risky" actions to the options markets, reducing noise and volatility in the stock market, leading to lower volatility. Another potential reason is the new opportunities for arbitrageurs to make riskless profits from mis-pricing is reduced, helping to stabilise the market at fair valuation. Faff and Hillier (2003) argue that the changing mix of investors in the stock market (less speculators and less informed traders; therefore greater proportion of uninformed traders) is a causal reason behind observed listing effects.

Table 2.1: Predicted Change of Characteristics according to Framework

\begin{tabular}{cccc}
\hline \hline Characteristic & $\begin{array}{c}\text { Complete } \\
\text { Markets }\end{array}$ & $\begin{array}{c}\text { Diminishing Short Sales } \\
\text { Restrictions }\end{array}$ & $\begin{array}{c}\text { Improved Information } \\
\text { Environment }\end{array}$ \\
\hline \hline Price/Returns & Positive & Negative & $\begin{array}{c}\text { Either - positively related to future } \\
\text { expectations } \\
\text { Lolatility }\end{array}$ \\
Lower & Lower & $\begin{array}{c}\text { Lower } \\
\text { Volume }\end{array}$ \\
& Higher & Unclear & $\begin{array}{c}\text { Unclear }- \text { informed trading aspect } \\
\text { suggests lower, while increased } \\
\text { profile aspect suggests higher }\end{array}$ \\
\hline \hline
\end{tabular}

Table 2.1 summarises the expected impacts on each of the underlying stocks characteristics, according to the three major theoretical frameworks. It can be seen that the three theoretical frameworks provide no conclusive prediction as to the predicted changes in the underlying stock

\footnotetext{
${ }^{19}$ In contrast to Lang, Lins \& Miller (2003), it could be suggested that improving the information environment for small firms will most likely result in negative price impacts. Large firms have many analysts researching the company and are more likely to uncover negative information. Smaller firms with few analysts can more easily hide negative information, thus when the level of coverage increases it is more likely that analysts will uncover negative information, leading to negative returns. Further development of this theory is left to future research.
} 
characteristics around derivative listing. As discussed below, price effects have been found in either direction; therefore it would seem that during certain times, one effect may dominate another.

Conrad (1989) used 1973-1980 US data to examine the price effect of introducing an option. She filtered the earliest observations due to an expected learning curve, whose existence may influence true effects. Her findings show significant positive price effects in the underlying security, which begin 3 days prior to introduction. Conrad (1989) concludes this positive shift to be permanent, as there is no price reversal in the subsequent time period. Conrad (1989) uses a liquidity pressure explanation to explain her findings. She argues that dealers create demand pressures on the underlying stock in anticipation of writing covered option positions. Unfortunately, this argument does not hold true for put options, where the reverse hedge is required, but Conrad (1989) does not examine this in detail as her data is primarily call listings. Conrad's (1989) conclusions are based on the assumption that the writer of the call option will hedge their position by being long in the underlying security. However, many strategies - such as spreads, straddles or naked calls - do not require holding the underlying security. As such Conrad's (1989) conclusion that demand pressures cause the price rise may not be accurate, as they may only be minimal increased demand. Conrad (1989) does not analyze trading volume, which may indicate whether there was actually increased demand for the underlying stock. Haddad \& Vorrheis (1991) also use US data and find results consistent with Conrad (1989), being significantly positive abnormal returns. Broughton \& Smith (1997) improve Conrad's (1989) methodology by removing potentially confounding effects, such as profit announcements or M\&A activity. Their findings still support Conrad (1989), but at lower levels of significance of positive abnormal returns.

DeTemple \& Jorian (1990) also find positive abnormal returns in support of Conrad (1989). However, they find in the post-1980 period, the listing effect becomes less pronounced. They also find an increase in prices (albeit at statistically non-significant levels) of related securities that did not have options listed on them. DeTemple \& Jorian (1990) conclude that there is a cross-listing effect, where related securities can be imperfectly hedged with the options on the original security ${ }^{20}$, which causes the price change in the related security. This may also explain

\footnotetext{
${ }^{20}$ For example, many stocks in the same industry have high correlations, eg the banking industry. If an option is available on one bank, then an investor can hedge their exposure to another bank through purchase of the option.
} 
the diminishing listing effect ${ }^{21}$. DeTemple \& Jorian (1990) note that larger firms were the first to have options. They argue that the lower option listing effects may be due to smaller firms having a lesser impact, due to the related securities effect; however they do not empirically test this hypothesis. This is in contrast to the improved information environment theory predictions, which expect that smaller firms will have greater impacts due to increased coverage and profile. Schniski \& Long (1995) examine firm size effect and find, in contrast to DeTemple \& Jorian (1990) untested small-firm hypothesis and in support of the improved information environment theory, that smaller firms have greater positive price effects than larger firms. Schniski \& Long (1995) actually find negative returns for largest firms in their sample.

Kim \& Young (1991) specifically examine the effects of put listings. They find no significant effects on the stock price following put introductions, supporting to the theory that puts are redundant securities. Their study also extends previous research by examining subsequent option introduction $^{22}$. Again, they find no significant price effects. Kim \& Young (1991) conclude that introducing a call option increases the state-space and potential risk/return combinations sufficiently to the point where the markets are complete. The diminishing short sales theory however predicts that introducing a put will allow negative information to be incorporated into the stock price, thus causing negative shocks, which is in contrast to Kim \& Young's (1991) empirical results. Put option introduction is also examined by Damodaran \& Lim (1991b) who find a negative price effect, in contrast to Kim \& Young (1991).

The price/introduction relationship has also been extensively studied outside the US markets. Draper, Mak \& Tang (2001) study the relationship between derivative warrant ${ }^{23}$ listing and stock price in the Hong Kong market. Although they find significant positive price effects they also find that the effect appears to be temporary ${ }^{24}$ with a reversal inside five days, which is in contrast to Conrad (1989). Chen \& Wu's (2001) examination of the Hong Kong market produced the

\footnotetext{
${ }^{21}$ As more options are introduced, most securities would already have an imperfect quasi hedge available through options on a related security. Therefore the market is already significantly complete, thus no (or lower) listing effects for latter option listing.

${ }^{22}$ The subsequent option introduction is where an option already listed on one stock exchange is listed on a second exchange at a later date.

${ }^{23}$ Derivative warrants in the Hong Kong markets are essentially the same as the derivative warrants this study is testing the Australian market. Draper et al (2001) are only testing puts and calls, as the more exotic products (such as installment, barriers and PIE's) are not available or exchange traded in Hong Kong.

${ }^{24}$ Conrad (1989) explained her findings to demand pressures by dealers anticipating writing covered position. If this were the explanation, then the price movement should reverse subsequent to listing as demand pressures decrease. The findings of Draper et al (2001) and Watt et al (1992) more accurately reflect this process.
} 
same findings. The UK market has been examined by Watt, Yadav \& Draper (1992) and Faff \& Hillier (2003). Both find positive price impacts, but again that the effect is only temporary. As stated previously, the diminishing short-sales restrictions hypothesis, and the improved information environment hypothesis in the case where informed traders have negative outlooks, both predict a negative price impact. Ho \& Liu (1995) argue that introducing options leads to an increase in the quantity and speed which negative information can be incorporated into the market, which should therefore lead to negative abnormal returns. Their empirical findings of negative abnormal returns support these theorems, and are also supported by recent research by Mayhew \& Mihov (2003) and Danielson \& Sorescu (2001).

While majority of research has used abnormal return methodology, Mayhew \& Mihov (2000) utilise a control sample methodology. They find evidence that pre-1980 there was a positive abnormal return, however in the post-1980 period, they find significant negative returns. Although their findings are in contrast to other research, their methodology was also unique amongst research in this area. Importantly, none of the control samples accurately match their (non-control) sample, with each control group matching only a single characteristic - beta, variance or size - but none match more than one characteristic. Their different results may be a result of the different methodology used. This is further highlighted by the significantly negative cumulative abnormal returns found in some of the control groups ${ }^{25}$.

Despite the weakness of Mayhew \& Mihov's (2000) methodology, their conclusions are supported by Sorescu (2000). Using a two-regime switching model to test for a structural break, Sorescu (2000) also finds that pre-1981 there was a positive abnormal return, which became negative in the post-1981 period. Sorescu (2000) argues that this may be due to either a learning effect (similar to Conrad, 1989), a market completeness effect (index options were introduced around this time, possibly completing the market) or a structural change in the capital markets (the period is characterised by a series of major reform and deregulation).

The diminishing short sales restrictions predict that the level of short interest in the stock should increase around the introduction of the option. Danielson \& Sorescu (2001) argue that the negative price effects found are due to increased levels of short interest in the stock, which they show to increase by $95 \%$, around option introduction. They therefore conclude that listing

\footnotetext{
${ }^{25}$ Abnormal returns due to an event should not, by definition, be found in control groups selected for the reason that the event has not occurred.
} 
options expedites some of the restriction on short-sales, allowing informed traders with negative outlooks to enter the market, thus causing the negative abnormal return. Mayhew \& Mihov (2000), Sorescu (2000) and Danielson \& Sorescu (2001) do not attempt to ascertain whether their findings are permanent or temporary adjustments. 
Table 2.2: Summary of Previous Research into Price Impacts

\begin{tabular}{|c|c|c|c|c|}
\hline Study & Comments & Sample & Returns & Magnitude \\
\hline Conrad (1989) & Call listings & $1973-1980$ & Positive & $\begin{array}{l}4 \% \text { for days }-3 \text { to } \\
+1\end{array}$ \\
\hline $\begin{array}{l}\text { DeTemple \& } \\
\text { Jorian (1990) }\end{array}$ & $\begin{array}{l}\text { Findings of diminishing effects in } \\
\text { post } 1980 \text { period }\end{array}$ & $1973-1986$ & Positive & $\begin{array}{l}2.8 \% \text { for weeks }-1 \\
\text { to }+1\end{array}$ \\
\hline $\begin{array}{l}\text { Damodaran \& } \\
\text { Lim (1991b) }\end{array}$ & Puts & $1977-1984$ & Negative & $\begin{array}{l}-1.2 \% \text { for days }-10 \\
\text { to }+10\end{array}$ \\
\hline $\begin{array}{c}\text { Haddad \& } \\
\text { Vorrheis }(1991)\end{array}$ & & $1973-1986$ & Positive & $\begin{array}{l}\text { Not clear in tables } \\
\text { presented }\end{array}$ \\
\hline $\begin{array}{l}\text { Kim \& Young } \\
\quad(1991)\end{array}$ & $\begin{array}{l}\text { 1. Put listings } \\
\text { 2. Subsequent Call listings }\end{array}$ & $1973-1987$ & $\begin{array}{l}\text { 1. None } \\
\text { 2. None }\end{array}$ & \\
\hline $\begin{array}{l}\text { Watt, Yadav \& } \\
\text { Draper (1992) }\end{array}$ & UK & $1978-1989$ & Positive & $\begin{array}{l}+1.3 \% \text { for days }-10 \\
\text { to }+1\end{array}$ \\
\hline $\begin{array}{l}\text { Long \& Schniski } \\
\qquad(1995)\end{array}$ & $\begin{array}{l}\text { Size effects } \\
\text { (1) Large firms } \\
\text { (2) Mid firms } \\
\text { (3) Small firms }\end{array}$ & $1985-1990$ & $\begin{array}{l}\text { (1) Negative } \\
\text { (2) Negative } \\
\text { (3) Positive }\end{array}$ & $\begin{array}{l}\text { *all }-10 \text { to }+10 \text { days } \\
\text { (1) }-3.28 \% \\
\text { (2) }-3.32 \% \\
\text { (3) }+2.06 \%\end{array}$ \\
\hline Ho \& Liu (1995) & & $1983-1990$ & Negative & $\begin{array}{l}-7.4 \% \text { reversal } \\
\text { from }-100 \text { days to } \\
+100 \text { days }\end{array}$ \\
\hline $\begin{array}{l}\text { Broughton \& } \\
\text { Smith (1997) }\end{array}$ & Removes confounding effects & $1973-1986$ & Positive & $\begin{array}{l}+3.08 \% \text { for days }-5 \\
\text { to }+5\end{array}$ \\
\hline $\begin{array}{l}\text { Mayhew \& } \\
\text { Mihov (2000) }\end{array}$ & $\begin{array}{l}\text { Control Group methodology } \\
\text { Some control groups showed } \\
\text { abnormal effects (Type I errors) }\end{array}$ & $1975-1991$ & Negative & $\begin{array}{l}-1.7 \% \text { for days }-5 \text { to } \\
+5\end{array}$ \\
\hline Sorescu (2000) & $\begin{array}{l}\text { Tests for structural break at ' } 81 \\
\text { (1) Pre } 1981 \\
\text { (2) Post } 1981\end{array}$ & $1973-1995$ & $\begin{array}{l}\text { (1) Positive } \\
\text { (2) Negative }\end{array}$ & $\begin{array}{l}* \text { all }-5 \text { to }+5 \text { days } \\
\text { (1) }+2.98 \% \\
\text { (2) }-0.9 \%\end{array}$ \\
\hline $\begin{array}{l}\text { Chen \& Wu } \\
\text { (2001) }\end{array}$ & Hong Kong & $1989-1997$ & Positive & $\begin{array}{l}+1.33 \% \text { for days }-2 \\
\text { to }+1\end{array}$ \\
\hline $\begin{array}{l}\text { Draper, Mak \& } \\
\text { Tang }(2001)\end{array}$ & Hong Kong & $1993-1996$ & Positive & $\begin{array}{l}+1 \% \text { for days }-2 \text { to } \\
+2\end{array}$ \\
\hline $\begin{array}{l}\text { Danielson \& } \\
\text { Sorescu (2001) }\end{array}$ & $\begin{array}{l}\text { Links increase in short interest to } \\
\text { price effect } \\
\text { (1) Pre } 1980 \\
\text { (2) Post } 1980\end{array}$ & $1973-1995$ & $\begin{array}{l}\text { (1) Positive } \\
\text { (2) Negative }\end{array}$ & $\begin{array}{l}* \text { all }-5 \text { to }+5 \text { days } \\
\text { (1) }+2.98 \% \\
\text { (2) }-1.4 \%\end{array}$ \\
\hline $\begin{array}{l}\text { Faff \& Hillier } \\
\qquad(2003)\end{array}$ & UK & $1978-1999$ & Positive & $+2.5 \%$ on Day 0 \\
\hline
\end{tabular}


In summary, the impact derivative option listing has on the underlying securities price is varied across studies and time. Early studies by Conrad (1989), Haddad \& Vorrheis (1991) and Watt, Yadav \& Draper (1992) find positive excess returns at highly significant levels, which they attribute to the market becoming complete. Later studies, starting with DeTemple \& Jorian (1990), who find a diminishing positive effect post-1980, find returns more consistent with the diminishing short-sales restrictions hypothesis or the improved information environment hypothesis. Studies by Ho \& Liu (1995), Mayhew \& Mihov (2000) and Danielson \& Sorescu (2001) all find significantly negative abnormal returns for the post 1980 period.

The general frameworks that explain the impact of option introduction predict positive impacts on volume. The complete market theory suggests that new investors will be drawn to the underlying security because of improved opportunity sets, whilst the improved information environment theory predicts that increased profile associated with option introduction will encourage new investors, but at the potential cost of informed traders leaving the stock market to access the benefits found in the options market.

Long, Schniski \& Officer (1994) examine whether size will have an impact on the level of changes following option introduction. They find that subsequent to option introduction, average trading volume for all firms increased by over 28\%. Long et al (1994) also finds that the number of trades' increases even more. This indicates smaller non-institutional investors may be entering the market, perhaps due to the increased profile, which is consistent with the improved information environment hypothesis, though Long et al (1994) do not discuss this. They find that the smallest and mid-size firms experience the most significant effects. Their findings support the hypothesis that introducing an option will increase investor interest in the underlying security. Although not discussed, this finding is important for regulators. Regulators should be concerned that the options market offers incentives such as leverage, low frictions and low scrutiny of activities, which may cause the underlying security to become illiquid as investors move to the more attractive option market ${ }^{26}$. However, Long et al's (1994) findings of greatly increased volume allay this concern.

Findings by Kumar, Sarin \& Shastri (1998) support Long et al (1994). Kumar et al (1998) find that introducing options increases the market quality of the underlying asset, as measured by

\footnotetext{
${ }^{26}$ While recently regulators have generally not held an official position regarding introducing new derivatives, evidence of some concern is obvious from the moratorium restricting new option listings that the SEC placed on options exchanges between 1979 and 1981. This is discussed in Conrad (1989).
} 
liquidity. They define liquidity/market quality as volume, quote depth and bid-ask spreads offered by market makers, and find positive effects in each of the variables post option listing. Long et al's (1994) study is also supported by findings by Ho \& Liu (1995) and Mayhew \& Mihov (2000), who find comparable changes in volume. Ho \& Liu (1995) extend the analysis by examining the volatility of the volume, but find no significant changes. In contrast to Ho \& Liu (1995), an earlier study by Whiteside, Dukes \& Dunne (1983) found a significant increase in the volatility of volume. Whiteside et al (1983) results must be tempered by the older time period (1973-1979), which may not be reflective of contemporary impacts, as evidence by changing impacts on price.

Volume changes have also been tested in the Hong Kong and UK markets. Draper, Mak \& Tang (2001) and Chen \& Wu (2001) both examine the Hong Kong market and find significant increases in trading volume around option introduction. Draper et al (2001) extend the analysis and find that volume remains permanently higher subsequent to introduction. Faff \& Hillier (2003) use a regression model to test changes in volume in the UK market, with a dummy variable for each of the ten days subsequent to option introduction. Consistent with other studies, they find a significant increase in trading volume; however by only testing up to ten days after the option introduction, their results are not reflective of a permanent upward shift. 
Table 2.3: Summary of Previous Research into Volume Impacts

\begin{tabular}{|c|c|c|c|}
\hline Study & Comments & Period & Volume Change \\
\hline $\begin{array}{l}\text { Long, Schinski \& } \\
\text { Officer (1994) }\end{array}$ & $\begin{array}{l}\text { Size effects } \\
\text { 1. Large firms } \\
\text { 2. Mid firms } \\
\text { 3. Small firms }\end{array}$ & $1985-1990$ & $\begin{array}{c}\text { Increase in relative volume } \\
\text { 1. }+0.29 \% \\
\text { 2. }+3.33 \% \\
\text { 3. }+4.59 \%\end{array}$ \\
\hline $\begin{array}{c}\text { Kumar, Sarin \& Shastri } \\
\text { (1998) }\end{array}$ & $\begin{array}{l}\text { Tests market quality } \\
\text { 1. Trading Volume } \\
\text { 2. Bid-ask spread } \\
\text { 3. Depth }\end{array}$ & $1983-1989$ & $\begin{array}{l}\text { 1. Increase } \\
\text { 2. Increase } \\
\text { 3. Decrease }\end{array}$ \\
\hline Ho \& Liu (1995) & $\begin{array}{l}\text { 1. Volume } \\
\text { 2. Variance of Volume }\end{array}$ & $1973-1986$ & $\begin{array}{l}\text { 1. } 19 \% \text { increase } \\
2.7 .7 \% \text { increase }\end{array}$ \\
\hline $\begin{array}{l}\text { Whiteside, Dukes \& } \\
\text { Dunne (1983) }\end{array}$ & $\begin{array}{l}\text { Random Sample } \\
\text { 1. Volume } \\
\text { 2. Variance of Volume }\end{array}$ & $1973-1981$ & $\begin{array}{l}\text { 1. Increase } \\
\text { 2. Increase }\end{array}$ \\
\hline Faff \& Hillier (2003) & Dummy Regression, UK & $1978-1999$ & Increase \\
\hline
\end{tabular}

While price effects seem to have changed over time, volume impacts have remained consistently positive. While some researchers (eg Faff \& Hillier, 2003) suggest that insiders or speculators will shift their activities to the derivatives market, resulting in lower volume in the underlying security, empirical results suggest a complete markets effect or improved information environment effect dominates the impact.

Conrad (1989), in addition to examining the price change, looked at changes in unconditional variance and beta. She found that variance decreased significantly following option introduction; however she also found that beta was unchanged. Later research by DeTemple \& Jorian (1990) and St Pierre (1998) support Conrad's (1989) findings of decreased volatility and unchanged beta, while Haddad \& Vorrheis (1991) find decreased volatility at the same time as significantly decreased beta. In an earlier paper, Whiteside, Dukes \& Dunne (1983), find that, in the short-term, variance decreased subsequent to option introduction. Skinner (1989) uses a before/after ratio to determine the change in variance, and also concludes that variance has fallen. Skinner (1989) extends the research by linking the change in variance to the observed change in liquidity ${ }^{27}$.

\footnotetext{
${ }^{27}$ Generally, the more liquid a stock is, the lower the risk for an individual investor due to the ability to quickly liquidate a position at a fair price. This is then transferred into observed lower variance of stock prices. As
} 
Niendorf \& Peterson (1997) find results consistent with Conrad (1989) in earlier periods. However in the post-1987 period, they find minimal and statistically non-significant changes in variance. They conclude that in later years the market has become more complete and efficient. Thus observed changes in earlier periods are not applicable to current market conditions.

Also in contrast to Conrad (1989) and St Pierre (1998) is research by Long, Schinski \& Officer (1994), who find no change in variance and no change in beta following option introduction. Using regression methodology linked to control groups, Freund, McCann \& Webb (1994) show that variance remains unchanged for later listings (1986 to 1990), also in contrast to previous findings.

While the majority of US studies use call options, Elfkani \& Chuadhury (1997) test the introduction of put options, in the Canadian market. They too find a decrease in variance, but in addition also find decreased systematic risk. They conclude that the differences to US studies are due to tighter restrictions on short selling in the Canadian markets, which are reduced with the introduction of puts. Due to the similarities between the Canadian and US regulatory frameworks, and the fact that many large Canadian companies use US exchanges to raise capital, results may not be indicative of world wide effects. Draper, Mak \& Tang (2001) examine changes in volatility in Hong Kong, and though they find volatility decreases in over $80 \%$ of all stocks, average volatility actually increases.

In contrast to Draper et al (2000), but in support of Conrad (1989), Watt, Yadav \& Draper (1992) find lower variance and no change in beta in the UK market. Contradicting this, Faff \& Hillier (2003) use a GARCH modelling technique with a dummy variable to find an increase in variance following option introduction. This must be tempered by the fact they only test for up to 10 days subsequent to listing, to remove any bias caused by confounding events. However, higher volatility may be experienced during the time around the listing date ${ }^{28}$ therefore Faff \& Hillier's (2003) results may not reflect a permanent change.

Research into derivative listing effects in Australia has been very limited. However, McKenzie, Brailsford \& Faff (2001) tested the introduction of Individual Stock Futures (ISF). Using

discussed in section 2.4, volume (as a proxy for market liquidity) has invariably been found to increase post option introduction.

${ }^{28}$ This can be seen by the vast differences in results found regarding price changes. If the price is changing by a statistically significant margin, this indicates an obvious change in volatility around the issue date. 
GARCH modelling techniques and a control sample methodology, they found a general reduction in the volatility as well as a decrease in systematic risk. These results are tempered by the fact that all ten ISF's are on highly liquid and large Australian companies. Thus results may not be indicative of smaller firms due to the inherent differences regarding their information environments and investor characteristics. The significance of this paper to the current study is the fact that these companies may therefore already have completed markets due to the ISF and short-sales restrictions are significantly diminished ${ }^{29}$, thus we would expect a lower listing effect of warrants.

In summary, introducing the exchange traded option decreased the standard measures of risk associated with the security. While Faff \& Hillier (2003) find an increase in variance, they are only testing for short term effects, and thus may not be reflective of a permanent change. An important note is that in majority of cases variance changed, but systematic risk - as measured by beta - has generally stayed unchanged.

Table 2.4 Summary of Previous Research into Risk Impacts

\begin{tabular}{|c|c|c|c|}
\hline Study & Comments & Period & Result \\
\hline Conrad (1989) & $\begin{array}{l}\text { 1. Unconditional Variance } \\
\text { 2. Beta }\end{array}$ & $1973-1980$ & $\begin{array}{c}\text { 1. } 83 \text { out of } 96 \text { firms decreased } \\
\text { 2. No change }\end{array}$ \\
\hline $\begin{array}{l}\text { DeTemple and } \\
\text { Jorian (1990) }\end{array}$ & $\begin{array}{l}\text { 1. Variance } \\
\text { 2. Beta }\end{array}$ & $1973-1986$ & $\begin{array}{l}\text { 1. } 14 \% \text { decrease } \\
\text { 2. } 2 \% \text { decrease }\end{array}$ \\
\hline St Pierre (1998) & $\begin{array}{c}\text { Calls only } \\
\text { Uses an EGARCH equation }\end{array}$ & $1973-1990$ & $\begin{array}{l}\text { Decrease in unconditional } \\
\text { variance, no change in conditional } \\
\text { variance }\end{array}$ \\
\hline $\begin{array}{l}\text { Damodaran and } \\
\operatorname{Lim}(1991)\end{array}$ & $\begin{array}{l}\text { 1. Variance } \\
\text { 2. Decomposes variance into } \\
\text { intrinsic factor and noise } \\
\text { factor. }\end{array}$ & $1973-1983$ & $\begin{array}{l}\text { 1. } 28.6 \% \text { decrease } \\
\text { 2. } 40 \% \text { decrease in noise } \\
\text { component }\end{array}$ \\
\hline $\begin{array}{c}\text { Haddad and } \\
\text { Vorrheis (1991) }\end{array}$ & $\begin{array}{l}\text { 1. Variance } \\
\text { 2. Beta }\end{array}$ & $1973-1986$ & $\begin{array}{l}\text { 1. } 7.3 \% \text { decrease } \\
\text { 2. } 2.8 \% \text { decrease }\end{array}$ \\
\hline $\begin{array}{l}\text { Whiteside, Dukes } \\
\text { and Dunne (1983) } \\
\text { Niendorf and }\end{array}$ & $\begin{array}{l}\text { Random Sample only } \\
\text { Tests short term only } \\
\text { 1. Pre } 1987\end{array}$ & $\begin{array}{l}1973-1980 \\
1985-1991\end{array}$ & $\begin{array}{c}\text { Decrease in variance (exact level } \\
\text { not clear from tables) }\end{array}$ \\
\hline
\end{tabular}

\footnotetext{
${ }^{29}$ Traders with negative expectations can sell a futures contract.
} 


\begin{tabular}{|c|c|c|c|}
\hline Peterson (1997) & 2. Post 1987 & & $\begin{array}{l}\text { 1. } 77.3 \% \text { of firms decreased var. } \\
\text { 2. } 54.5 \% \text { of firms decrease var. }\end{array}$ \\
\hline $\begin{array}{l}\text { Long, Schinski } \\
\text { and Officer (1994) }\end{array}$ & $\begin{array}{l}\text { 1. Variance } \\
\text { 2. Beta }\end{array}$ & $1985-1990$ & $\begin{array}{l}\text { 1. Unchanged } \\
\text { 2. Unchanged }\end{array}$ \\
\hline $\begin{array}{l}\text { Chaudhury and } \\
\text { Elfakhani (1997) }\end{array}$ & $\begin{array}{l}\text { Put options in Canada } \\
\text { 1. Variance } \\
\text { 2. Mkt. adj. Variance }\end{array}$ & $1975-1990$ & $\begin{array}{l}\text { 1. } 70 \% \text { of firms decreased var. } \\
\text { 2. } 57 \% \text { of firms decreased var. }\end{array}$ \\
\hline $\begin{array}{l}\text { Draper, Mak and } \\
\text { Tang }(2000)\end{array}$ & $\begin{array}{c}\text { Hong Kong. GARCH equation } \\
\text { 1. Variance }\end{array}$ & $1993-1996$ & 1. $80 \%$ of firms decrease var. \\
\hline $\begin{array}{l}\text { Watt, Yadav and } \\
\text { Draper (1992) }\end{array}$ & $\begin{array}{l}\text { UK } \\
\text { 1. Variance } \\
\text { 2. Beta }\end{array}$ & $1978-1989$ & $\begin{array}{l}\text { 1. } 25.3 \% \text { decrease } \\
\text { 2. No change }\end{array}$ \\
\hline $\begin{array}{l}\text { Faff and Hillier } \\
\qquad(2003)\end{array}$ & $\begin{array}{l}\text { UK. GARCH equation. } 10 \\
\text { day post event limit. }\end{array}$ & $1978-1999$ & $\begin{array}{l}\text { Dummy variable indicates } \\
\text { significant increase in volatility }\end{array}$ \\
\hline
\end{tabular}

The extensive literature on option, warrant and other derivative listing effects has produced varied yet significant results. While price effects have been slow to vary across time; with early periods showing positive abnormal returns, but latter studies showing a negative abnormal return; volume and risk effects have generally remained consistently positive. While no framework can accurately describe all the effects found, a combination of the three theories seems to explain most of the impacts.

The diversity of findings, especially regarding price, makes it diffficult to predict what the impacts will be for Australian derivative warrant introduction. This makes this research particularly important for our understanding of the efficiency of the Australian financial markets, and whether introducing new exotic derivatives will have an impact or whether they are merely redundant securities.

\section{DATA AND METHODOLOGY}

As stated in Section 1, event study methodology is a common and powerful test to examine the impact an event (in this case warrant introduction) has on the underlying security. Consistent will all the previous literature in the field, the listing date is examined, which has the additional advantage of being distinctly observable, a vital requirement for a successfully event study. 
The methodology used throughout the literature, as shown in Section 2, has been varied. Some authors have used a control group methodology (eg Mayhew \& Mihov, 2000) and some have used dummy variable regression techniques (eg Faff \& Hillier, 2003). However, the vast majority of research has used standard abnormal returns methodology. This study uses similar methodology, such as that adopted in Conrad (1989) and Sorescu (2000), due to its relative power when examining smaller sample sizes. An ancillary benefit to using similar methodology is that it allows for direct comparison of results found in previous research.

Hypothesis construction regarding expected change in stock characteristics due to warrant introduction is difficult. The theoretical models (section 2.2) and empirical findings (sections 2.3 to 2.5 ) show contrasting and sometimes directly opposite results. The following hypotheses are therefore selected.

$H_{0}$ : Derivative warrant introduction will have no impact on the underlying stocks price, volume and/or risk measures.

$H_{1}$ : Derivative warrant introduction will cause either a positive or negative impact on the underlying stocks price, volume and/or risk measures.

As the null hypothesis predicts no change, acceptance that the warrant caused a change in the underlying stocks characteristics will only be shown if proven at statistically significant levels ( $p$-values either $1 \%, 5 \%$ or $10 \%$ ) using two-tailed tests for significance.

The listing effects will be examined on warrants that have been newly issued since 1997. Conrad (1989) notes a potential "learning bias", where the listing effects of the earliest options may be biased because they are introduced in a market with limited or no experience of them. The post 1997 period has therefore been selected for three reasons. First, it excludes any potential learning biases, as observed by Conrad (1989). Second, the warrants market in Australia was very small prior to 1997 , but subsequently has grown at an exponential rate, almost doubling in size every year, as shown in Figure 1.1. Third, the period includes approximately equal time lengths of a "bull market" (1997-2000) and a "bear market" (20002003). Therefore, any biases that are introduced due to general market feeling and sentiment are reduced. 
The data set tested only includes the first time issue of a particular warrant on a particular company. If the same style warrant had been introduced pre-1997, it is excluded. In addition, due to the high similarities of options to call and put warrants, these warrants are also excluded if the option was listed prior to the warrant ${ }^{30}$.

Stock price data is sourced from Almax Information Systems, and is adjusted for splits, bonus issues, and other capital reconstructions. Index data is sourced from Standard and Poors. Warrant details, including the listing date and type of warrant, are obtained directly from the $\mathrm{ASX}^{31}$. All warrants listed in the period January 1997 to January 2003 are obtained, though only first time issues of each type of warrant are selected.

The listings have also been filtered based on available data. Companies must have 250 days of returns prior to and after the listing date ${ }^{32}$. A final filter is applied, in that companies that are involved in major merger and/or acquisition activity ${ }^{33}$ during the relevant 500 day period are also filtered out.

With all exclusions our dataset includes the follow numbers of stocks on each style of warrant.

Table 3.1: Count of First Time Warrants

\begin{tabular}{lcc}
\hline \hline Type of Warrant & $\begin{array}{c}\text { No of companies before } \\
\text { filters applied }\end{array}$ & Final No. Tested \\
\hline Call & $111^{*}$ & 53 \\
Put & $54^{*}$ & 26 \\
Barrier Calls & 16 & 12 \\
Capped Calls & 13 & 7 \\
COS & 14 & 12 \\
HOTS & 48 & 41 \\
Instalments & 68 & 51 \\
PIE & 11 & 10 \\
\hline *Calls and Puts were primarily filtered due to having an option prior to the warrant (42 and 22 respectively)
\end{tabular}

\footnotetext{
${ }^{30}$ A separate test is made for the securities where options were listed prior to warrants, which is not presented here. It was found that companies with calls or put warrants listed after options were already available had no impact on the underlying security.

${ }^{31}$ The author extend thanks to the anonymous employees of the ASX who assembled the warrant data set.

${ }^{32}$ While this creates some survivorship bias leading to over-estimation of returns, it actually further reinforces findings (see sections 4 and 5) where, in general, negative returns have been found. Including de-listed companies is likely to have lead to even greater negative returns.

${ }^{33}$ This was done by performing internet based searches for new stories regarding the relevant company. It is acknowledged that some major events may have been missed, however applying the imperfect filter is still an improvement on various studies (eg Conrad, 1989) who do not apply the filter.
} 
While it is recognised that some categories, especially capped calls, have small sample sizes, abnormal return methodology is robust for small sample sizes or even for a single firm.

It must be noted that larger companies, such as ASX top 20, have little representation in the overall call and put warrant categories, due having the earlier listings of warrants and options. As a result it is acknowledged that results are biased towards the small capitalisation stocks in these categories. This may be an advantage this study has over its contemporaries for the purpose of predicting future listing impacts, as new listings are more likely to be on younger, smaller firms. For the new, more innovative warrant products such as HOTS and Instalments, companies are more evenly represented by size. Cursory data examination shows no GICS industry concentration.

In following with previous papers (eg Conrad, 1989, DeTemple \& Jorian, 1990), an abnormal returns approach has been selected to examine the price effects. This allows the results from this study to be directly compared to studies in the US, UK and Hong Kong, as well as avoiding the portfolio selection problems involved in control group methodologies, as seen in Mayhew \& Mihov (2000).

Price data is obtained from end-of-day prices in each stock, and dates placed in event time, where day 0 is the first date of warrant trading (the listing date). The listing date was chosen due to previous findings being unanimous that the announcement date of the option/warrant introduction has no impact on the stock (eg Whiteside, Dukes \& Dunne, 1981). Due to the sensitivity of event studies to using the correct event date, data is obtained direct from the ASX. To determine the stocks "normal" return a 245-day time window prior to listing is used. Normal returns are estimated from the period -250 days to -5 days, accounting for approximately one year of trading time. This method is consistent with many event studies (eg Brown \& Warner, 1985), and is considered powerful as it avoids monthly seasonality ${ }^{34}$.

A -5 to +5 day time-period is used to examine the actual abnormal and cumulative abnormal returns. While chosen rather arbitrarily, it is based on the previous research that generally finds price impacts around that time-frame (eg Conrad, 1989, who finds impacts between days -3 to $+2)$.

\footnotetext{
${ }^{34}$ Monthly seasonality, such as the "January" effect, has been extensively examined. Brailsford \& Heaney (1997, ch. 13) present a concise review of previous research in this area, both in the Australian and international markets. Included two sets of Januaries (in particular, but other months as well) would bias expectations.
} 
Figure 3.2: Event Time

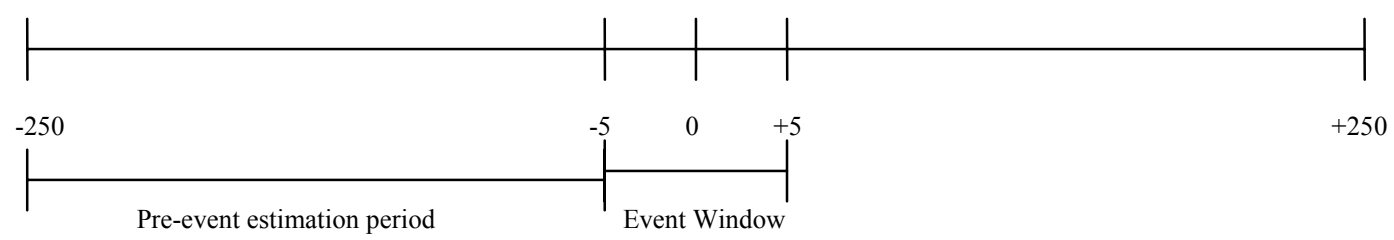

To calculate abnormal returns robustly, two methods are used. While Dyckman, Philbrick \& Stephen (1984) and Cable \& Holland (1999) both find that the market model is the most powerful and accurate method, the primary method use here is a mean reversion model, with a market model used as secondary support. The market model predicts stock returns using a correlation term (beta) between the overall market and the actual return. The market model generally has an advantage over the mean reversion model as it removes any systematic effects that may induce abnormal returns incorrectly. However, the market model is only particularly useful when event dates are all on the same day or within a close cluster. The event days in this study are widely dispersed, so no single systematic event will influence results, therefore the primary reason for using a market adjusted model is missing.

As recommended by McKinley (1997), the market index used is a broad based, value weighted, accumulation style index. For the purpose of this study, the index chosen is the S\&P ASX200 Accumulation Index. Hereafter, all mention of market returns refer to returns calculated on this index. All returns are calculated on a continuously compounded basis.

The models used are presented below.

Mean Reversion Model:

$\mathrm{AR}_{\mathrm{jt}}=\mathrm{R}_{\mathrm{jt}}-\mathrm{e}\left(\mathrm{R}_{\mathrm{j} t}\right)$

Market Model:

$\mathrm{AR}_{\mathrm{jt}}=\mathrm{R}_{\mathrm{jt}}-\beta\left(\mathrm{R}_{\mathrm{mt}}\right)$

Where AR is the abnormal return to stock $j$ on day $i, R_{j}$ is the continuously compounded return on stock $\mathrm{j}$ on day $\mathrm{i}, \mathrm{e}\left(\mathrm{R}_{\mathrm{jt}}\right)$ is the historical mean of the continuously compounded returns over the preceding 245 day period, $R_{m}$ is the continuously compounded return on the market index on day $\mathrm{i}$, and $\beta$ is equal to the historical beta of the stock, as calculated by the correlation between the 
returns to the market and the returns to the index. To overcome the problem of thin trading the Scholes Williams (1977) beta is used.

To determine significance, standard deviations of the stocks daily continuously returns are calculated, with any returns outside the mean \pm 2 standard deviation range considered significant at the 5\% level. This is illustrated in Figure 3.3. Note, the methodology is robust for a single stock, therefore if, on average, multiple stocks consistently display significantly abnormal returns, the result is quite robust.

Figure 3.3: Abnormal Returns and Significance

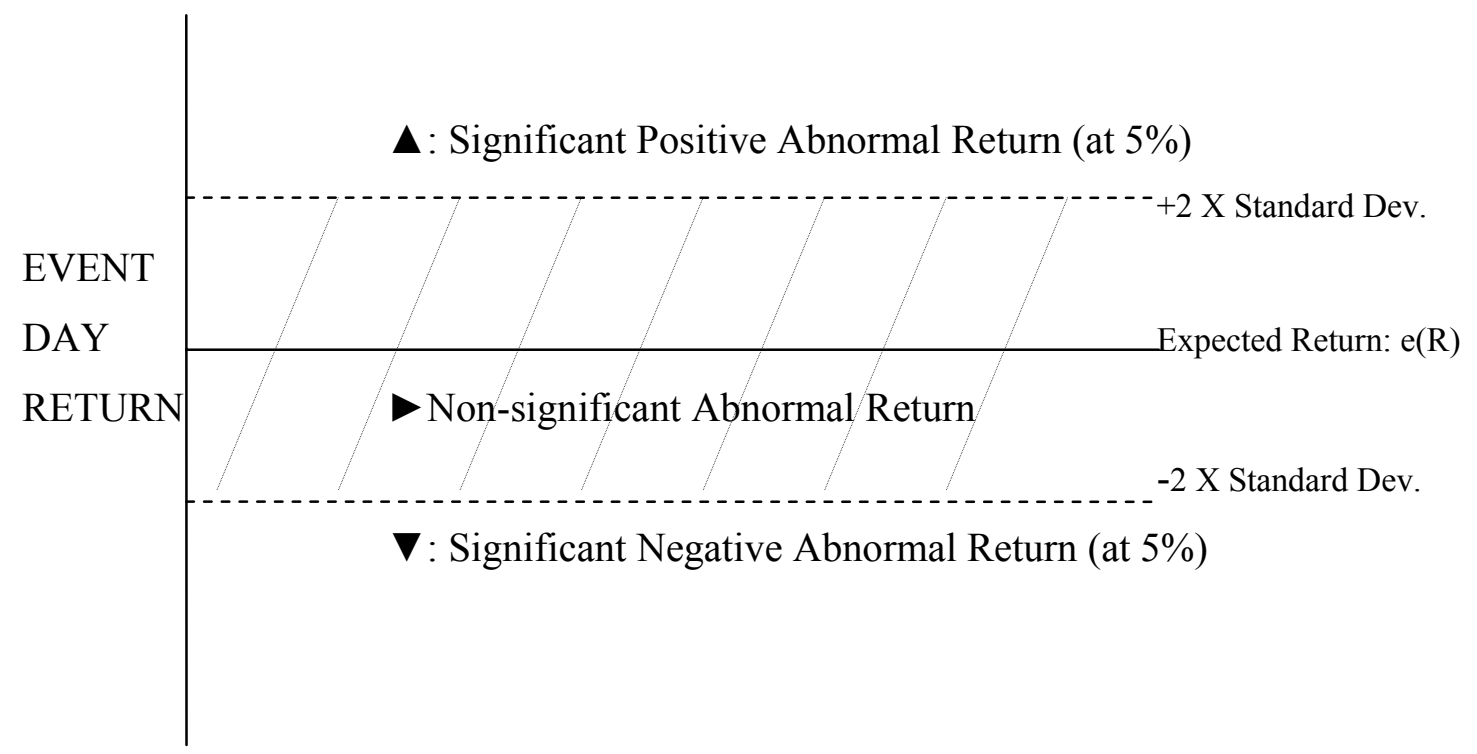


Volume in stocks is a highly volatile factor, often with large variances, generally non-normal distributions and many outliers, of which examination of our data-set confirmed. Therefore an exponential smoothing process is first applied to the data to normalise the volume. Standard deviations and variance will be calculated from these normalised volume figures.

To determine whether the event caused a permanent change in volume, the average normalised volume in the 250 days prior to the warrant introduction will first be compared to the average normalised volume in the 250 days subsequent to the warrant introduction. This method is comparable to that used by Damodaran \& Lim (1991) and Watt, Yadav \& Draper (1992). Significance is determined using a $t$-test for change in mean.

A second test is also run. Generally over time trading volume for stocks may increase. Therefore, a dummy variable regression will be used that considers this trend, and using a dummy variable to find if the volume still significantly changed. The t-test for change in means will not capture this effect. Faff \& Hillier (2003) use a dummy variable regression; however they do not consider any underlying trend which may bias the results of the dummy variable ${ }^{35}$. The regression equation used in this research is presented below, with significance of variables calculated using standard measures.

$V_{i t}=\alpha_{i}+\beta_{1} D A Y+\beta_{2} D U M M Y+\varepsilon_{i t}$

where $V_{n}$ is the volume on day $n, \alpha$ is the constant, $\beta$ is the co-efficient of the relevant variables, DAY is -250 to +250 being the time-series variable, and DUMMY is 0 for the pre-listing period and 1 for the post-listing period.

Consistent with studies by Watt, Yadav \& Draper (1992) and Damodaran \& Lim (1991), a ratio of pre-warrant variance to post-warrant variance will be calculated and an f-test applied. Variances will be calculated for 250 days each side of the warrant introduction date.

New techniques for determining change in volatility have been presented by Becchetti \& Caggese (2000) and Faff \& Hillier (2003). Due to the close nature of the studies between Faff \& Hillier (2003) and this study, the GARCH methodology used by Faff \& Hillier (2003) will also be adopted here. Faff \& Hillier (2003) do not show or describe their estimation model, thus

\footnotetext{
${ }^{35}$ The existence of any underlying positive trend will lead to results that will invariably indicate a significant increase in trading volume between the pre- and post- listing periods. The results will not reflect that the event caused the change, but rather that a key explanatory variable is missing.
} 
a generalised estimation model ${ }^{36}$ is used to generate the residuals required for the GARCH analysis. The estimation model is shown below.

$R_{j}=\alpha_{i}+\beta_{1} I N D E X+\beta_{2} R_{j t-1}+\varepsilon_{i t}$

where $R_{j}$ is the returns on stock $j$ in time t, $\alpha$ is a constant, $\beta$ is the co-efficients for the relevant variable, INDEX is the value of the ASX200 $R_{j, t-1}$ is an auto-regressive term for the return in stock j.

The GARCH methodology checks the residuals, or error terms, from the pre-specified predictive model and adjusts the variance measure for any auto-correlation or heteroskedasticity in said residuals. The joint test problem ${ }^{37}$ is recognised, but not controlled for in any manner. The GARCH model is considered more powerful than a variance measure due to its consideration of auto-correlation and heteroskedasticity in residual terms.

As GARCH estimation is only used in this paper as an additional measure of variance/volatility, an in-depth discussion of the GARCH process will not be presented. For a detailed description of the GARCH process, see for example, Bollerslev (1986).

Due to existence of potentially confounding events Faff and Hillier (2003) only used a dummy variable for up to 10 days subsequent to option listing. Many events cause short term increases in volatility of the stock price, as information is impounded, and the Faff and Hillier (2003) methodology will capture any short-term effects around option introduction. Unfortunately, as Faff and Hillier (2003) note, no current method is completely accurate over the long run due to the existence of confounding events.

As discussed above, due to the trading characteristics of the sample firms, utilising more complex beta measures will not add strength to the analysis. Therefore, to determine whether the option listing causes any change on the systematic risk of the firm Black (1993) beta is used.

\footnotetext{
${ }^{36}$ It should be noted that significance of GARCH and Dummy variable results is sensitive to the estimation model adapted. The general model used here was chosen arbitrarily, with discussion and input from peers influencing the final choice.

${ }^{37}$ The joint test problem is whether the equation used to estimate the residuals is applicable - for example, key variables may be omitted or the variables included may be the result of data mining bias. The variance equation will then be inaccurate due to the inaccuracy of the mean equation. The joint test problem occurs throughout financial literature, but it is anticipated that results from the GARCH process will be comparable to results from the ratio $f$-tests, thus adding to the robustness of findings.
} 
Black's (1993) beta is the co-efficient term between the index and the stock price, with no adjustment for the risk-free rate.

The ordinary least squares regression model will be calculated between the lognormal returns of the security and the lognormal returns of the market index, for the 250 days prior to option introduction and again for the 250 days subsequent to the option introduction.

A dummy variable regression analysis is used, with dummy variables testing for an absolute shift and for a change in the slope of the correlation (change in beta). The equation used is shown below, with significance of regressors calculated in standard ways.

$R_{j}=\alpha_{j}+\beta_{1} I N D E X+\beta_{2}(I N D E X \times D U M M Y)+\beta_{3} D U M M Y+\varepsilon_{i t}$

where $R_{j}$ is the return to stock $j, \alpha$ is a constant, $\beta$ is the co-efficients for the relevant variable, INDEX is the value of the ASX 200 and DUMMY is 0 for the pre-listing period and 1 for the post-listing period.

INDEX X DUMMY tests for the change in correlation between the stock price and the index (i.e. change in beta), while DUMMY tests for a shift in the constant term. The results from INDEX X DUMMY determine whether the warrant listing has caused a significant change in beta.

Use of event study methodology generates powerful and robust results. In this paper, two sets of abnormal returns are calculated using a mean reversion model and a market adjusted model to remove systematic effects. A change in volume is tested using both a t-test for change in mean and a dummy variable regression. The Scholes Williams (1977) beta is calculated, and a change is tested by using a dummy variable regression technique. Change in unconditional variance is determined using an $f$-test, while a GARCH regression model tests for a change in conditional variance.

Using two or more methods to examine the impact warrant listing has on each of the underlying securities characteristics generates particularly robust results, especially if all methods indicate similar findings. Section 4 presents those results, with brief commentary highlighting important points and Section 5 continues with an in-depth discussion of the results. 


\section{RESULTS}

Results are presented in table format with significance shown using p-values and asterix (*) where there is statistical significance. A full discussion of results and how they fit within the theoretical frameworks and comparisons with previous finding are reserved for Section 5, with only brief comments made throughout this section to highlight important empirical findings.

For the price effects, the tables are split into two panels. Panel A shows the single daily abnormal return, and Panel B shows the Cumulative Abnormal Returns across various combinations of days. If the option listing has caused a price effect, significant results in day 0 , and possible significance in day -1 and day +1 should be found. Significance should be lower the further from the event date.

For CARS, the significance of longer periods (eg days -5 to day +5 ) or periods not inclusive of the event (eg days -5 to day -2) should show lower significance than periods around the event date (eg days -1 to +1 or days -2 to +2 ). Consistent with the literature on this methodology (eg Brown \& Warner, 1985), CAR's are considered a more powerful indicator; therefore the CAR results are the focus of discussion.

Results for volume, variance and beta are shown in aggregated tables, with all types of warrants shown. Results for price effects are presented first, followed by results for volume effects, variance effects, beta effects and finishing with skewness effects.

Table 4.1 shows the abnormal returns for the first time listing of call warrants. Due to the relatively large sample size, the fact that call warrants were the first type of warrant to be introduced on a stock in most cases and their relatively importance in the warrants market, call warrants are considered here to be the most important warrant to study.

Call warrants were generally the first warrant listed on a company with $56.2 \%$ of warrants having a call first (27\% of companies have an instalment first, with the remainder spread across the other warrants approximately evenly. Under the complete markets hypothesis, call warrants and instalment warrants (table 4.5 ) should therefore have the most significant positive effects, as they are the biggest contributors to "completing the market".

However, Table 4.1 shows calls warrants experienced significant negative cumulative abnormal returns over the period, with period -1 to +1 showing a $-3.02 \%$ abnormal return (significant at $1 \%$ ). The event day itself showed an abnormal return of $-1.38 \%$, however this is found to be 
non-significant. From this, it would appear that the complete markets theorem does not hold, though the diminishing short-sales restrictions hypothesis (which predicts a negative price impact around warrant introduction) or the improved information environment hypothesis may explain the results.

Put warrants, under the redundant securities theory (eg Kim \& Young, 1991), are expected to have no price impacts, however under the diminishing short-sales restrictions hypothesis and improved information environment hypotheses are expected to have a negative price impact. Table 4.2 illustrates that on day 0 stocks with put warrants issued on them experienced a negative $1.87 \%$ abnormal return, which is significant at the $5 \%$ level. Cumulative abnormal returns through the event window are also consistently negative, with day -1 to day +1 showing a negative $3.18 \%$ abnormal return, significant at the $1 \%$ level. These results strongly confirm that introducing put warrants results in a negative price impact on the underlying security, which is consistent with the diminishing short sales restrictions hypothesis and the improved information environment hypothesis.

Table 4.3 displays the abnormal return results when barrier call warrants are listed. A significantly negative abnormal return of $2.14 \%$ (sig. at $1 \%$ ) is found on the day prior to warrant introduction (day -1), with day 0 showing no significant change. A reversal is then shown on the day subsequent to warrant listing, with a positive abnormal return of $2.14 \%$ (sig. at $1 \%$ ). There were no significant market adjusted returns throughout the period. As is expected by a large move followed by a reversal, the CAR's are shown to be insignificant around the event period. From this we can conclude that barrier call introduction has no permanent price impact on the stock price.

Capped call introduction results in significant abnormal positive returns on the day of introduction of $2.07 \%$, followed by a significant negative abnormal return of $1.80 \%$ on the day subsequent to introduction, as shown in Table 4.4. However, the market adjusted returns are not found to be significant and there are no significant cumulative abnormal returns; therefore we conclude that capped call introduction has no permanent impact on the stock price.

Table 4.5 shows results for COS warrant introduction. There are no highly significant returns around the event date; however we find significant negative cumulative abnormal returns of $2.78 \%$ (sig. at $1 \%$ ) between days -1 to +1 . Despite the finding non-significance of individual 
day abnormal returns, the introduction of a COS warrant can be seen to cause a negative price impact on the underlying stock.

Similar to COS warrant introduction, the price impact of introducing HOTS warrants occurred over several days, not on a single day. Table 4.6 shows non-significance of individual day abnormal returns, however a abnormal negative $2.16 \%$ return is found between days -2 to +2 , indicating that introduction of a COS warrant results in a negative price impact on the underlying stock.

All four of the warrants discussed above are typically shorter term, speculative instruments.

Barrier call and capped call are very similar (see Appendix A), therefore similar results are easily explained. The COS and HOTS warrants results of negative price impact may be explained by a signalling hypothesis by the writer/ issuer of such instruments.. 
Table 4.1: Returns During Event Window - Call Warrants

Panel A shows the abnormal returns as calculated from a mean reversion model (AR) and the market adjusted model (MAR), as described in section 3.3.1. Panel B shows the cumulative abnormal returns over a variety of time periods within the event window.

Panel A: Abnormal Returns (AR) and Market Adjusted Abnormal Returns (MAR)

\begin{tabular}{ccccc}
\hline \hline Day & AR & AR & MAR & MAR \\
\hline & $\%$ return & $p$-value & $\%$ return & $p$-value \\
\cline { 2 - 5 }-5 & $0.9703 \%$ & 0.2389 & $0.8888 \%$ & 0.2686 \\
-4 & $1.6041 \%$ & $0.0521^{\star \star}$ & $1.8444 \%$ & $0.0222^{\star \star}$ \\
-3 & $-0.1934 \%$ & 0.8141 & $-0.1992 \%$ & 0.8040 \\
-2 & $0.5799 \%$ & 0.4811 & $0.2194 \%$ & 0.7846 \\
-1 & $-1.1992 \%$ & 0.1458 & $-1.2639 \%$ & 0.1161 \\
0 & $-1.3814 \%$ & $0.0941^{\star}$ & $-1.1301 \%$ & 0.1598 \\
1 & $-0.4356 \%$ & 0.5965 & $-0.4126 \%$ & 0.6072 \\
2 & $-1.1420 \%$ & 0.1659 & $-0.9807 \%$ & 0.2223 \\
3 & $0.3783 \%$ & 0.6457 & $0.4542 \%$ & 0.5715 \\
4 & $-0.3960 \%$ & 0.6303 & $-0.5172 \%$ & 0.5194 \\
5 & $0.1693 \%$ & 0.8370 & $0.5587 \%$ & 0.4865 \\
\hline \hline
\end{tabular}

Panel B: Cumulative Abnormal Returns (CAR) for different combinations of days in event window

\begin{tabular}{ccc}
\hline \hline Time & CAR & p-value \\
\hline-5 to -2 & 0.0296 & 0.5266 \\
-4 to 0 & -0.0059 & 0.3706 \\
-4 to +4 & -0.0219 & $0.0739^{\star}$ \\
-5 to +5 & -0.0105 & 0.1650 \\
-2 to +5 & -0.0343 & $0.0193^{\star \star}$ \\
-1 to +1 & -0.0302 & $0.0100^{\star \star \star}$ \\
-2 to +2 & -0.0358 & $0.0100^{\star \star \star}$ \\
-3 to +3 & -0.0339 & $0.0198^{\star \star}$ \\
-3 to +5 & -0.0362 & $0.0154^{\star \star}$ \\
0 to +5 & -0.0281 & $0.0397^{\star \star}$ \\
\hline \hline
\end{tabular}

$\mathrm{N}=53$

* $\quad$ Represents significance level at $10 \%$

** Represents significance level at 5\%

*** Represents significance level at $1 \%$ 
Table 4.2: Returns During Event Window - Put Warrants

Panel A: Abnormal Returns (AR) and Market Adjusted Abnormal Returns (MAR)

\begin{tabular}{ccccc}
\hline \hline Day & AR & AR & MAR & MAR \\
\hline & $\%$ return & P-value & $\%$ return & $p$-value \\
\cline { 2 - 5 }-5 & $0.2557 \%$ & 0.7560 & $0.3106 \%$ & 0.6128 \\
-4 & $-0.5077 \%$ & 0.5373 & $-0.2413 \%$ & 0.6942 \\
-3 & $0.2379 \%$ & 0.7725 & $0.3780 \%$ & 0.5381 \\
-2 & $-0.3339 \%$ & 0.6849 & $-0.1969 \%$ & 0.7483 \\
-1 & $-1.1069 \%$ & 0.1793 & $-0.7862 \%$ & 0.2008 \\
0 & $-1.8696 \%$ & $0.0238 * \star$ & $-1.5121 \%$ & $0.0143 * \star$ \\
1 & $-0.2016 \%$ & 0.8064 & $-0.0714 \%$ & 0.9074 \\
2 & $-0.4091 \%$ & 0.6191 & $-0.4390 \%$ & 0.4745 \\
3 & $0.3776 \%$ & 0.6463 & $0.8166 \%$ & 0.1840 \\
4 & $0.8050 \%$ & 0.3283 & $0.8646 \%$ & 0.1596 \\
5 & $-1.1383 \%$ & 0.1673 & $-0.9909 \%$ & 0.1072 \\
\hline \hline
\end{tabular}

Panel B: Cumulative Abnormal Returns (CAR) for different combinations of days with event window

\begin{tabular}{ccc}
\hline \hline Time & CAR & p-value \\
\hline-5 to -2 & -0.0035 & 0.6586 \\
-4 to 0 & -0.0358 & $0.0084^{\star \star \star}$ \\
-4 to +4 & -0.0301 & $0.0674^{\star}$ \\
-5 to +5 & -0.0389 & $0.0351^{\star \star}$ \\
-2 to +5 & -0.0388 & $0.0175^{\star \star}$ \\
-1 to +1 & -0.0318 & $0.0026^{\star \star *}$ \\
-2 to +2 & -0.0392 & $0.0042^{\star \star \star}$ \\
-3 to +3 & -0.0331 & $0.0317^{\star \star}$ \\
-3 to +5 & -0.0364 & $0.0312^{\star \star}$ \\
0 to +5 & -0.0244 & $0.0875^{\star}$ \\
\hline \hline
\end{tabular}

$\mathrm{N}=26$

* $\quad$ Represents significance level at $10 \%$

** $\quad$ Represents significance level at 5\%

*** Represents significance level at $1 \%$ 
Table 4.3: Returns During Event Window - Barrier Call Warrants

Panel A: Abnormal Returns (AR) and Market Adjusted Abnormal Returns (MAR)

\begin{tabular}{ccccc}
\hline \hline Day & AR & AR & MAR & MAR \\
\hline & $\%$ return & $P$-value & $\%$ return & $p$-value \\
\cline { 2 - 5 }-5 & $2.4729 \%$ & $0.0029^{\star \star \star}$ & $1.5281 \%$ & 0.4566 \\
-4 & $-0.7787 \%$ & 0.3443 & $-1.5445 \%$ & 0.4518 \\
-3 & $3.7027 \%$ & $0.0000^{\star \star \star}$ & $2.5838 \%$ & 0.2086 \\
-2 & $3.0151 \%$ & $0.0003^{\star \star \star}$ & $2.7822 \%$ & 0.1759 \\
-1 & $-2.1386 \%$ & $0.0098^{\star \star \star}$ & $-2.8913 \%$ & 0.1596 \\
0 & $-0.2859 \%$ & 0.7282 & $-0.4889 \%$ & 0.8116 \\
1 & $2.1437 \%$ & $0.0096^{\star \star \star}$ & $1.2535 \%$ & 0.5414 \\
2 & $-1.9058 \%$ & $0.0212^{\star \star}$ & $-2.8870 \%$ & 0.1602 \\
3 & $0.5243 \%$ & 0.5241 & $0.7224 \%$ & 0.7248 \\
4 & $-3.2082 \%$ & $0.0001^{\star \star \star}$ & $-2.3250 \%$ & 0.2577 \\
5 & $-1.2872 \%$ & 0.1186 & $-2.6067 \%$ & 0.2046 \\
\hline \hline
\end{tabular}

Panel B: Cumulative Abnormal Returns (CAR) for different combinations of days with event window

\begin{tabular}{ccc}
\hline Time & CAR & p-value \\
\hline-5 to -2 & 0.0841 & 0.5815 \\
-4 to 0 & 0.0351 & 0.9739 \\
-4 to +4 & 0.0107 & 0.3940 \\
-5 to +5 & 0.0225 & 0.4324 \\
-2 to +5 & -0.0314 & 0.1215 \\
-1 to +1 & -0.0028 & 0.5103 \\
-2 to +2 & 0.0083 & 0.5607 \\
-3 to +3 & 0.0506 & 0.9471 \\
-3 to +5 & 0.0056 & 0.3477 \\
0 to +5 & -0.0402 & $0.0921^{\star}$ \\
\hline
\end{tabular}

$\mathrm{N}=12$

* Represents significance level at $10 \%$

** Represents significance level at 5\%

*** Represents significance level at 1\% 
Table 4.4: Returns During Event Window - Capped Call Warrants

Panel A: Abnormal Returns (AR) and Market Adjusted Abnormal Returns (MAR)

\begin{tabular}{ccccc}
\hline \hline Day & AR & AR & MAR & MAR \\
\hline & $\%$ return & P-value & \% return & p-value \\
\cline { 2 - 5 }-5 & $-4.2765 \%$ & $0.0000^{\star \star \star}$ & $-3.2330 \%$ & 0.11747 \\
-4 & $0.1409 \%$ & 0.8640 & $-0.2609 \%$ & 0.89921 \\
-3 & $-1.1158 \%$ & 0.1758 & $-1.3127 \%$ & 0.52416 \\
-2 & $-1.2994 \%$ & 0.1151 & $-1.0740 \%$ & 0.60226 \\
-1 & $0.4836 \%$ & 0.5568 & $0.5047 \%$ & 0.80647 \\
0 & $2.0706 \%$ & $0.0124^{\star \star}$ & $1.7787 \%$ & 0.38828 \\
1 & $-1.8036 \%$ & $0.0291^{\star \star}$ & $-0.8526 \%$ & 0.67902 \\
2 & $-3.3349 \%$ & $0.0001^{\star \star \star}$ & $-2.0557 \%$ & 0.31885 \\
3 & $-1.5491 \%$ & $0.0606^{\star}$ & $-1.3807 \%$ & 0.50292 \\
4 & $1.2325 \%$ & 0.1350 & $0.9117 \%$ & 0.65814 \\
5 & $6.7594 \%$ & $0.0000^{\star \star *}$ & $5.9784 \%$ & $0.00400^{\star \star \star}$ \\
\hline \hline
\end{tabular}

Panel B: Cumulative Abnormal Returns (CAR) for different combinations of days with event window

\begin{tabular}{ccc}
\hline Time & CAR & p-value \\
\hline-5 to -2 & -0.0655 & 0.191704 \\
-4 to 0 & 0.0028 & 0.895388 \\
-4 to +4 & -0.0518 & 0.286324 \\
-5 to +5 & -0.0269 & 0.488176 \\
-2 to +5 & 0.0256 & 0.864142 \\
-1 to +1 & 0.0075 & 0.95498 \\
-2 to +2 & -0.0388 & 0.319018 \\
-3 to +3 & -0.0655 & 0.180341 \\
-3 to +5 & 0.0144 & 0.965037 \\
0 to +5 & 0.0337 & 0.669826 \\
\hline \hline
\end{tabular}

$\overline{\mathrm{N}=7}$

* Represents significance level at 10\%

** Represents significance level at 5\%

*** Represents significance level at $1 \%$ 
Table 4.5: Returns During Event Window - COS Warrants

Panel A: Abnormal Returns (AR) and Market Adjusted Abnormal Returns (MAR)

\begin{tabular}{ccccc}
\hline \hline Day & AR & AR & MAR & MAR \\
\hline & $\%$ return & $P$-value & $\%$ return & $p$-value \\
\cline { 2 - 5 }-5 & $-1.3097 \%$ & 0.1123 & $-1.2288 \%$ & $0.01089^{\star *}$ \\
-4 & $-1.0704 \%$ & 0.1940 & $-0.9068 \%$ & $0.05950^{\star}$ \\
-3 & $-1.0515 \%$ & 0.2019 & $-0.2224 \%$ & 0.64285 \\
-2 & $1.4257 \%$ & $0.0840^{\star}$ & $1.1153 \%$ & $0.02069^{\star \star}$ \\
-1 & $-1.0476 \%$ & 0.2036 & $-0.5046 \%$ & 0.29314 \\
0 & $-0.9720 \%$ & 0.2381 & $-0.4099 \%$ & 0.39299 \\
1 & $-0.7632 \%$ & 0.3540 & $-0.5080 \%$ & 0.28990 \\
2 & $-0.9123 \%$ & 0.2681 & $-0.9105 \%$ & $0.05846^{\star}$ \\
3 & $-0.3760 \%$ & 0.6477 & $-0.3347 \%$ & 0.48541 \\
4 & $0.7740 \%$ & 0.3472 & $0.7117 \%$ & 0.13858 \\
5 & $0.3342 \%$ & 0.6847 & $0.5704 \%$ & 0.23487 \\
\hline \hline
\end{tabular}

Panel B: Cumulative Abnormal Returns (CAR) for different combinations of days with event window

\begin{tabular}{ccc}
\hline \hline Time & CAR & p-value \\
\hline-5 to -2 & -0.0201 & $0.0539^{\star}$ \\
-4 to 0 & -0.0272 & $0.0073^{\star \star \star}$ \\
-4 to +4 & -0.0399 & $0.0020^{\star \star \star}$ \\
-5 to +5 & -0.0497 & $0.0004^{\star \star \star}$ \\
-2 to +5 & -0.0154 & 0.1039 \\
-1 to +1 & -0.0278 & $0.0019^{\star \star \star}$ \\
-2 to +2 & -0.0227 & $0.0200^{\star \star}$ \\
-3 to +3 & -0.0370 & $0.0016^{\star \star \star}$ \\
-3 to +5 & -0.0259 & $0.0250^{\star \star}$ \\
0 to +5 & -0.0192 & $0.0456^{\star \star}$ \\
\hline \hline
\end{tabular}

$\mathrm{N}=12$

* Represents significance level at 10\%

** Represents significance level at 5\%

*** Represents significance level at $1 \%$ 
Table 4.6: Returns During Event Window - HOTS Warrants

Panel A: Abnormal Returns (AR) and Market Adjusted Abnormal Returns (MAR)

\begin{tabular}{ccccc}
\hline \hline Day & AR & AR & MAR & MAR \\
\hline & $\%$ return & $P$-value & $\%$ return & $p$-value \\
\cline { 2 - 5 }-5 & $0.0066 \%$ & 0.9936 & $0.1463 \%$ & 0.62320 \\
-4 & $-1.0960 \%$ & 0.1836 & $-0.4990 \%$ & 0.09464 \\
-3 & $-0.0798 \%$ & 0.9227 & $0.0823 \%$ & 0.78223 \\
-2 & $-1.5823 \%$ & $0.0553^{\star}$ & $-1.1348 \%$ & $0.00017^{\star \star \star}$ \\
-1 & $-0.2102 \%$ & 0.7983 & $-0.1281 \%$ & 0.66714 \\
0 & $-0.3116 \%$ & 0.7049 & $0.2286 \%$ & 0.44288 \\
1 & $0.2314 \%$ & 0.7785 & $0.2801 \%$ & 0.34729 \\
2 & $-0.2846 \%$ & 0.7294 & $0.0636 \%$ & 0.83082 \\
3 & $-0.7017 \%$ & 0.3940 & $-0.3424 \%$ & 0.25075 \\
4 & $-0.4465 \%$ & 0.5874 & $-0.0609 \%$ & 0.83781 \\
5 & $-0.0598 \%$ & 0.9421 & $-0.1276 \%$ & 0.66833 \\
\hline
\end{tabular}

Panel B: Cumulative Abnormal Returns (CAR) for different combinations of days with event window

\begin{tabular}{ccc}
\hline \hline Time & CAR & p-value \\
\hline-5 to -2 & -0.0275 & $0.0006^{\star \star \star}$ \\
-4 to 0 & -0.0328 & $0.0000^{\star \star \star}$ \\
-4 to +4 & -0.0448 & $0.0000^{\star \star \star}$ \\
-5 to +5 & -0.0453 & $0.0000^{\star \star \star}$ \\
-2 to +5 & -0.0337 & $0.0001^{\star \star \star}$ \\
-1 to +1 & -0.0029 & 0.4181 \\
-2 to +2 & -0.0216 & $0.0021^{\star \star \star}$ \\
-3 to +3 & -0.0294 & $0.0002^{\star \star \star}$ \\
-3 to +5 & -0.0345 & $0.0001^{\star \star \star}$ \\
0 to +5 & -0.0157 & $0.0201^{\star \star \star}$ \\
\hline \hline
\end{tabular}

$\overline{\mathrm{N}}=41$

* Represents significance level at $10 \%$

** Represents significance level at 5\%

*** Represents significance level at 1\% 
Table 4.6 shows abnormal return results for the period around instalment warrant introduction. With no significant individual day abnormal returns or cumulative abnormal returns, it is clear that introducing instalment warrants have no impact on the underlying stocks price.

Table 4.7 shows results for PIE warrant introduction. Again, no individual day experienced abnormal returns. Cumulative abnormal returns were non-significant except over extended time frames, with day -5 to +5 showing significant abnormal returns of $-4.17 \%$ (sig. at $5 \%$ level).

Instalment and PIE warrants have longer maturities, with the average life of the instalment warrants being 10.5 years and PIE warrants being 2.5 years, therefore the extended time to maturity may be a reason for lack of impact on the underlying security around the introduction date.

It must be noted that the short time window used ( -5 days to +5 days) do not confirm whether our findings regarding changed price are permanent or temporary adjustments. A longer time window would be required to test for reversals further than 5 days from the event date. We can see from results regarding barrier call and capped call warrant introduction that there were almost immediate reversals within the event window selected. However, extending the window may not yield statistically significant results, as any reversal should occur almost instantaneously under efficient market paradigms. 
Table 4.6: Returns During Event Window - Instalment Warrants

Panel A: Abnormal Returns (AR) and Market Adjusted Abnormal Returns (MAR)

\begin{tabular}{ccccc}
\hline \hline Day & AR & AR & MAR & MAR \\
\hline & $\%$ return & P-value & $\%$ return & $p$-value \\
\cline { 2 - 5 }-5 & $-0.2343 \%$ & 0.7758 & $-0.0160 \%$ & 0.95619 \\
-4 & $0.2173 \%$ & 0.7917 & $0.3243 \%$ & 0.26495 \\
-3 & $-0.5677 \%$ & 0.4904 & $-0.5196 \%$ & 0.07466 \\
-2 & $0.1661 \%$ & 0.8400 & $0.2965 \%$ & 0.30793 \\
-1 & $0.4285 \%$ & 0.6026 & $0.6909 \%$ & $0.01804^{\star \star}$ \\
0 & $-0.0453 \%$ & 0.9561 & $0.2094 \%$ & 0.47132 \\
1 & $-0.0224 \%$ & 0.9782 & $-0.0219 \%$ & 0.94001 \\
2 & $-0.5662 \%$ & 0.4915 & $-0.6097 \%$ & $0.03668^{\star *}$ \\
3 & $0.4680 \%$ & 0.5696 & $0.2934 \%$ & 0.31304 \\
4 & $-0.6939 \%$ & 0.3993 & $-0.4771 \%$ & 0.10149 \\
5 & $0.4402 \%$ & 0.5927 & $0.5817 \%$ & $0.04615^{\star \star}$ \\
\hline \hline
\end{tabular}

Panel B: Cumulative Abnormal Returns (CAR) for different combinations of days with event window

\begin{tabular}{ccc}
\hline \hline Time & CAR & $p$-value \\
\hline-5 to -2 & -0.0042 & 0.2640 \\
-4 to 0 & 0.0020 & 0.7869 \\
4 to +4 & -0.0062 & 0.1831 \\
-5 to +5 & -0.0041 & 0.2492 \\
-2 to +5 & 0.0017 & 0.6214 \\
-1 to +1 & 0.0036 & 0.8447 \\
-2 to +2 & -0.0004 & 0.5590 \\
-3 to +3 & -0.0014 & 0.4315 \\
-3 to +5 & -0.0039 & 0.2669 \\
0 to +5 & -0.0042 & 0.2787 \\
\hline \hline
\end{tabular}

$\overline{\mathrm{N}=51}$

* Represents significance level at 10\%

** Represents significance level at 5\%

*** Represents significance level at $1 \%$ 
Table 4.7: Returns During Event Window - PIE Warrants

Panel A: Abnormal Returns (AR) and Market Adjusted Abnormal Returns (MAR)

\begin{tabular}{ccccc}
\hline \hline DAY & AR & AR & MAR & MAR \\
\hline & $\%$ return & P-value & $\%$ return & $p$-value \\
\cline { 2 - 4 }-5 & $-0.8436 \%$ & 0.3057 & $-0.2059 \%$ & 0.74991 \\
-4 & $-0.3430 \%$ & 0.6768 & $0.5455 \%$ & 0.39871 \\
-3 & $-0.4389 \%$ & 0.5938 & $-1.1309 \%$ & $0.08092^{*}$ \\
-2 & $0.4039 \%$ & 0.6235 & $0.5147 \%$ & 0.42589 \\
-1 & $-0.7099 \%$ & 0.3885 & $-0.2885 \%$ & 0.65526 \\
0 & $-0.1705 \%$ & 0.8358 & $-0.2318 \%$ & 0.71979 \\
1 & $-0.1952 \%$ & 0.8124 & $-0.3664 \%$ & 0.57067 \\
2 & $-0.8433 \%$ & 0.3059 & $-0.5977 \%$ & 0.35522 \\
3 & $-0.5535 \%$ & 0.5013 & $-0.1474 \%$ & 0.81956 \\
4 & $-0.0244 \%$ & 0.9764 & $0.0281 \%$ & 0.96534 \\
5 & $-0.4467 \%$ & 0.5872 & $-0.0660 \%$ & 0.91868 \\
\hline
\end{tabular}

Panel B: Cumulative Abnormal Returns (CAR) for different combinations of days with event window

\begin{tabular}{ccc}
\hline \hline Time & CAR & p-value \\
\hline-5 to -2 & -0.0122 & 0.3186 \\
-4 to 0 & -0.0126 & 0.3075 \\
-4 to +4 & -0.0287 & $0.0782^{\star}$ \\
-5 to +5 & -0.0417 & $0.0238^{\star \star}$ \\
-2 to +5 & -0.0254 & 0.1026 \\
-1 to +1 & -0.0108 & 0.3207 \\
-2 to +2 & -0.0152 & 0.2434 \\
-3 to +3 & -0.0251 & 0.1014 \\
-3 to +5 & -0.0298 & $0.0705^{\star}$ \\
0 to +5 & -0.0223 & 0.1237 \\
\hline \hline
\end{tabular}

$\overline{\mathrm{N}}=10$

* Represents significance level at $10 \%$

** Represents significance level at 5\%

*** Represents significance level at 1\% 
Volume results are tested using both a t-test for change in mean between the pre- and postwarrant listing periods, and a dummy variable regression, as outlined in Section 3 . As can be seen in Panel A of Table 4.9, warrant introduction resulted in highly significant increases in average volume after the warrant is introduced, when looking at a simple change in mean volume. However, as Panel B shows, after considering the generally upward trend in the trading volume, significantly negative dummy variables indicate that when barrier calls, capped calls, COS, and puts are introduced, there is a negative impact on volume. Significantly positive impacts are found following call warrant and PIE warrant introduction. These results are discussed further in Section 5.

As discussed in section 3, the change in variance is measured in two methods, using a f-test for change in variance and using a GARCH $(1,1)$ variance equation with a dummy variable. Results are presented in table 4.9, with brief notes highlighting important findings. Results are discussed in full in Section 5.

Panel A shows that capped call, put and call warrant introduction resulted in significantly decreased variance of returns between the pre-listing period and the post-listing period, though calls and put categories were only significant at the $10 \%$ level. Increases in variance are found for companies with instalment warrants issued (at the 10\% level) and PIE warrants issued (at the $1 \%$ level).

Panel B shows the variance equations using GARCH and ARCH. It can be seen that in many cases there is evidence of GARCH effects influencing the variance equation. After accounting for GARCH/ARCH effects, companies with capped calls issued on them show non significant change in variance. Companies with PIE warrants listed on them do still show significant reduction in conditional variance, as indicated by the highly significant dummy variable. Other than the capped call companies showing no change, the results in from the GARCH estimators are consistent with the variance f-tests, thus adding to the robustness of results. 
Table 4.8: Volume Results

Panel A shows a simple t-test for change in mean between the pre-listing and post-listing periods. We can see that volume has clearly increased (evidenced by very high t-statistics) between the two periods. Panel B checks if there is an underlying trend that may have resulted in the volume naturally increasing between the periods, by using a regression equation with the dummy variable testing for a structural break in the trend around the option introduction. The equation used to estimate volume is Volume $\mathrm{t}_{\mathrm{t}}=\mathrm{c}+\mathrm{b}_{1}(\mathrm{DAY})+\mathrm{b}_{2}(\mathrm{DUMMY})$, where the DAY is the time-series variable that checks for a trend, and DUMMY is 0 for the prewarrant period and 1 for the post-warrant period.

\begin{tabular}{|c|c|c|c|}
\hline & & \multirow{2}{*}{\multicolumn{2}{|c|}{$\begin{array}{l}\text { Panel A: Average Change between } \\
\text { periods }\end{array}$}} \\
\hline & \multirow[b]{2}{*}{$\mathrm{N}$} & & \\
\hline & & Change & $\begin{array}{l}t \text {-test for change in } \\
\text { mean }\end{array}$ \\
\hline Calls & 53 & Increase & 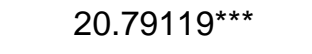 \\
\hline Puts & 26 & Increase & $12.12972^{\star \star \star}$ \\
\hline Barrier Call & 12 & Increase & $6.8401^{\star \star \star}$ \\
\hline Capped Call & 7 & Increase & $2.4347^{\star \star}$ \\
\hline cos & 12 & Increase & $9.5053^{\star \star \star}$ \\
\hline HOTS & 41 & Increase & $18.3843^{\star \star \star}$ \\
\hline Instalments & 51 & Increase & $8.9112^{\star \star \star}$ \\
\hline PIE & 10 & Increase & $3.9355^{\star \star \star}$ \\
\hline * $\quad$ Denotes sig & . & $0 \%$ & \\
\hline ** Denotes sig & nce & $\%$ & \\
\hline
\end{tabular}

\begin{tabular}{|c|c|c|c|c|}
\hline \multicolumn{5}{|c|}{ Panel B: Regression Results } \\
\hline & Intercept (c) & Trend (DAY) & DUMMY & $\begin{array}{l}\mathrm{R}^{2} \\
\left(\text { Adj } \mathrm{R}^{2)}\right)\end{array}$ \\
\hline co-efficient & 0.9857 & 0.0001 & 0.0131 & $0.524^{\star \star \star}$ \\
\hline$p$-value & $0.0000^{\star \star \star}$ & $0.0000^{\star \star \star}$ & $0.0009 * \star \star$ & $(0.522)^{\star \star \star}$ \\
\hline co-efficient & 1.0073 & 0.0001 & -0.0093 & $0.322^{\star \star \star}$ \\
\hline$p$-value & $0.0000^{\star \star \star}$ & $0.0000^{\star \star \star}$ & $0.0132^{\star \star}$ & $(0.320)^{\star \star \star}$ \\
\hline co-efficient & 0.9802 & 0.0002 & -0.0176 & $0.179 * * \star$ \\
\hline$p$-value & $0.0000^{\star \star \star}$ & $0.0000^{\star \star \star}$ & $0.0429 * \star$ & $(0.176)^{\star \star \star}$ \\
\hline co-efficient & 0.9842 & 0.0001 & -0.0134 & $0.045^{\star \star \star}$ \\
\hline$p$-value & $0.0000^{\star \star \star}$ & $0.0000^{\star \star \star}$ & $0.0125^{\star \star}$ & $(0.042)^{\star \star \star}$ \\
\hline co-efficient & 0.9821 & 0.0001 & -0.0098 & $0.217^{\star \star \star}$ \\
\hline$p$-value & $0.0000^{\star \star \star}$ & $0.0000^{\star \star \star}$ & $0.0024^{\star \star \star}$ & $(0.214)^{\star \star \star}$ \\
\hline co-efficient & 1.0289 & 0.0001 & 0.0074 & $0.460^{\star \star \star}$ \\
\hline$p$-value & $0.0000^{\star \star \star}$ & $0.0000^{\star \star \star}$ & $0.0199 * \star$ & $(0.457)^{\star \star \star}$ \\
\hline co-efficient & 1.0202 & 0.0002 & -0.0083 & $0.206^{\star \star \star}$ \\
\hline$p$-value & $0.0000^{\star \star \star}$ & $0.0000^{\star \star \star}$ & 0.3511 & $(0.203)^{\star \star \star}$ \\
\hline co-efficient & 0.9870 & 0.0000 & 0.0027 & $0.367^{\star \star \star}$ \\
\hline$p$-value & $0.0000^{\star \star \star}$ & 0.1058 & 0.5348 & $(0.329)^{\star \star \star}$ \\
\hline
\end{tabular}


Table 4.9: Variance Results

Panel A shows the results from an F-test for change in variance between the pre-warrant period and post-warrant period for companies with each of the types of warrants listed. Panel B shows the results from a ARCH/GARCH variance regression with dummy variable. The residuals for the GARCH/ARCH variance equation are estimated from Return $=c+b_{1}$ INDEX $+b_{2} R_{E T U R N}$. . The variance equation is VARIANCE $=c+b_{1} A R C H(1,1)+$ $b_{2} \operatorname{GARCH}(1,1)+b_{3}$ DUMMY, where the dummy variable is 0 for the pre-warrant period and 1 for the postwarrant period.

Panel A: Change In Standard Deviation

\begin{tabular}{lccccc}
\hline \hline & & & \multicolumn{3}{c}{ Standard Deviation (St.Dev) } \\
\cline { 3 - 5 } & & & & & F-test for change in \\
& & & Post-listing & \\
Type & 53 & Pre-listing St.Dev & St.Dev & \% Change & $0.0828^{\star}$ \\
\hline Calls & 26 & 0.0082 & 0.0074 & $-9.48 \%$ & $0.0825^{\star}$ \\
Puts & 12 & 0.0063 & 0.0056 & $-11.11 \%$ & 0.7301 \\
Barrier Calls & 7 & 0.0210 & 0.0206 & $-1.71 \%$ & $0.0000^{\star \star \star}$ \\
Capped Calls & 12 & 0.0060 & 0.0141 & $-33.53 \%$ & 0.1303 \\
COS & 41 & 0.0042 & 0.0068 & $13.13 \%$ & 0.5974 \\
HOTS & 51 & 0.0032 & 0.0042 & $-0.46 \%$ & $0.0883^{\star}$ \\
Instalments & 10 & 0.0081 & 0.0036 & $10.80 \%$ & $0.0057^{\star \star \star}$ \\
PIES & & 0.0097 & $19.57 \%$ & \\
\hline \hline
\end{tabular}

Panel B: GARCH/ARCH Variance Regressions

\begin{tabular}{|c|c|c|c|c|c|c|}
\hline & & CONSTANT & $\operatorname{ARCH}(1,1)$ & GARCH $(1,1)$ & DUMMY & $\begin{array}{c}\mathrm{R}^{2} \\
\text { (Adj. } \mathrm{R}^{2} \text { ) }\end{array}$ \\
\hline \multirow[t]{2}{*}{ Calls } & co-efficient & 0.0000 & 0.0714 & 0.6239 & 0.0000 & $0.0756^{\star \star \star}$ \\
\hline & $p$-value & 0.1157 & $0.0158^{\star \star}$ & $0.0042^{\star \star \star}$ & 0.1739 & $(0.0624)^{\star \star \star}$ \\
\hline \multirow[t]{2}{*}{ Puts } & co-efficient & 0.0000 & 0.0232 & 0.8064 & 0.0000 & $0.0680^{\star \star \star}$ \\
\hline & $p$-value & 0.5421 & 0.4755 & $0.0080^{\star \star \star}$ & 0.5299 & $(0.0567)^{\star \star \star}$ \\
\hline \multirow[t]{2}{*}{ Barrier Calls } & co-efficient & 0.0000 & 0.0356 & 0.9514 & 0.0000 & $0.0963^{\star \star \star}$ \\
\hline & $p$-value & $0.0018^{\star \star \star}$ & $0.0002^{\star \star *}$ & $0.0000^{\star \star \star}$ & $0.0169 * \star$ & $(0.0853)^{\star \star \star}$ \\
\hline \multirow[t]{2}{*}{ Capped calls } & co-efficient & 0.0000 & 0.0437 & 0.9383 & 0.0000 & $0.1036^{\star \star \star}$ \\
\hline & $p$-value & $0.0019 * \star \star$ & $0.0000^{\star \star \star}$ & $0.0000^{\star \star \star}$ & 0.0945 & $(0.0927)^{\star \star \star}$ \\
\hline \multirow[t]{2}{*}{$\cos$} & co-efficient & 0.0000 & 0.1322 & -0.2567 & 0.0000 & $0.3957^{\star \star \star}$ \\
\hline & $p$-value & $0.0000 * \star \star$ & $0.0317^{\star \star}$ & 0.2849 & 0.3152 & $(0.3872) * \star \star$ \\
\hline \multirow[t]{2}{*}{ HOTS } & co-efficient & 0.0000 & 0.0333 & 0.3422 & 0.0000 & $0.5631^{\star \star \star}$ \\
\hline & $p$-value & 0.5948 & 0.4944 & 0.7755 & 0.5962 & $(0.5577)^{\star \star \star}$ \\
\hline \multirow[t]{2}{*}{ Instalments } & co-efficient & 0.0000 & 0.0513 & -0.3746 & 0.0000 & $0.1215^{\star \star \star}$ \\
\hline & $p$-value & $0.0442^{\star \star}$ & 0.1486 & 0.5553 & 0.1063 & $(0.1108) * \star *$ \\
\hline \multirow[t]{2}{*}{ PIES } & co-efficient & 0.0000 & -0.0274 & 1.0089 & 0.0000 & $0.3335^{\star \star \star}$ \\
\hline & $p$-value & $0.0398^{\star \star}$ & $0.0000^{\star \star \star}$ & $0.0000^{\star \star \star}$ & $0.0000 * * *$ & $0.3254^{\star * \star}$ \\
\hline
\end{tabular}

* Denotes significance at $10 \%$

** Denotes significance at 5\%

*** Denotes significance at $1 \%$ 
The beta of the stock was examined using a dummy variable regression, as outlined in Section 3. Panel A of table 4.10 shows large absolute changes in beta, which all appear to be quite large. Panel B shows the co-efficients for the dummy variable regression, and the results indicate that introduction of a warrant does not cause a change in the underlying stocks beta.

In all cases, the INDEX is shown to be a statistically significant explanatory variable describing the stock return. However, the dummy variable regressions shown in Panel B indicate that there was no change in Beta, at significant levels, following option introduction. This is shown by the non-significance of $p$-values for the INDEX $\mathrm{X}$ DUMMY variable.

The results of no change in beta are largely consistent with previous findings, such as Conrad (1989) and Long, Schniski \& Officer (1994).

In general, a negative price impact is found for many of the warrant listings, using either mean reversion or market adjusted models. While raw trading volume increases significantly between the pre- and post- listing periods, applying a dummy variable regression that includes a time-series trend line indicates that warrant introduction decreased in trading volume following put, barrier call, capped call, COS and HOTS warrant introduction. Call warrants are still found to have increased trading volume.

Ratio variance $f$-tests find mixed results regarding change in variance. Significant decreases in variance are found after call warrants, put warrants and capped call warrants are listed, but significant increases in variance are found after instalment warrants and PIES warrants are introduced. After adjusted for $\operatorname{GARCH}(1,1)$ effects, it is found that only capped calls result in a significant change in variance, which must be tempered by their small sample size. Similarly, the dummy variable regressions show that introducing a warrant has no impact on the underlying securities beta value. 
Table 4.10: Beta Results

Panel A shows the average Beta for companies in the pre-warrant period compared to the post-warrant period, with the \% change between the periods also show. Panel B displays the results of the Dummy variable regression that is used to determine a change in Beta, with the equation being Returns $=\mathrm{c}+\mathrm{b}_{1} \mathrm{INDEX}+$ $\mathrm{b}_{2}$ (INDEX.DUMMY) $+\mathrm{b}_{3}$ DUMMY, where INDEX is the All Ordinaries return and DUMMY is 0 for the pre-warrant period and 1 for the post-warrant period. INDEX.DUMMY measures the change in the Scholes Williams Beta of the stock, while DUMMY tests for a shift in the constant. All co-efficients presented are means.

\begin{tabular}{|c|c|c|c|c|c|c|c|c|c|c|}
\hline & \multirow{2}{*}{$\mathrm{N}$} & \multicolumn{3}{|c|}{ Panel A: Mean Beta } & & \multicolumn{5}{|c|}{ Panel B: Dummy Variable Regressions } \\
\hline & & $\begin{array}{c}\text { Pre- } \\
\text { warrant }\end{array}$ & $\begin{array}{c}\text { Post- } \\
\text { warrant }\end{array}$ & $\begin{array}{c}\text { \% Change } \\
\text { between } \\
\text { periods }\end{array}$ & & CONSTANT & INDEX & INDEX * DUMMY & DUMMY & $\begin{array}{c}\mathrm{R}^{2} \\
\left(\text { Adj. } \mathrm{R}^{2} \text { ) }\right.\end{array}$ \\
\hline \multirow[t]{2}{*}{ Calls } & 53 & 0.842 & 0.544 & $-35.3 \%$ & co-efficient & 0.0018 & 0.8112 & -0.0651 & -0.0027 & 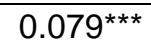 \\
\hline & & & & & $p$-value & $0.0004^{* \star *}$ & $0.0004^{\star \star \star}$ & 0.8368 & $0.0001^{\star \star \star}$ & $0.073^{\star \star \star}$ \\
\hline Puts & 26 & 0.8521 & 0.474 & & co-efficient & 0.0002 & 0.6476 & -0.1504 & -0.0005 & $0.070^{\star \star \star}$ \\
\hline \multirow[t]{2}{*}{ Barriers } & 12 & 1.302 & 2.068 & & co-efficient & 0.0066 & 1.2301 & 0.8648 & -0.0090 & $0.142^{\star \star \star}$ \\
\hline & & & & & $p$-value & $0.0000 * \star \star$ & $0.0004^{\star \star \star}$ & $0.0655^{\star}$ & $0.0000^{\star \star *}$ & $0.137^{\star \star \star}$ \\
\hline \multirow[t]{2}{*}{ Capped } & 7 & 0.863 & 1.15 & & co-efficient & 0.0012 & 0.8993 & 0.3296 & -0.0024 & $0.100^{\star \star *}$ \\
\hline & & & & & $p$-value & 0.2957 & $0.0000^{\star \star \star}$ & 0.2559 & 0.1311 & $0.095^{\star \star *}$ \\
\hline \multirow[t]{2}{*}{ cos } & 12 & 0.891 & 1.079 & & co-efficient & 0.0007 & 0.9210 & 0.1655 & -0.0004 & $0.399 * \star \star$ \\
\hline & & & & & $p$-value & $0.0243^{\star \star}$ & $0.0000 * \star \star$ & 0.1385 & 0.4246 & $0.399 * \star \star$ \\
\hline HOTS & 41 & 0.6785 & 0.892 & & co-efficient & 0.0006 & 0.7732 & 0.0958 & -0.0007 & $0.562^{\star * *}$ \\
\hline Instalments & & & & & $p$-value & $0.0459 * \star$ & $0.0000 * \star \star$ & $0.0496 * \star$ & 0.3915 & $0.124^{\star \star \star}$ \\
\hline \multirow[t]{2}{*}{ PIE } & 10 & 0.984 & 1.071 & & co-efficient & 0.0005 & 0.9627 & 0.1199 & -0.0006 & $0.334^{\star \star *}$ \\
\hline & & & & & $p$-value & 0.3192 & $0.0000^{\star \star \star}$ & 0.3581 & 0.3679 & $0.329 * \star *$ \\
\hline
\end{tabular}

* Denotes significance at $10 \%$

** Denotes significance at $5 \%$

*** Denotes significance at $1 \%$ 
The results presented in Section 4 show findings regarding price, variance and beta that are largely consistent with recent findings in the US (eg Danielson \& Sorescu, 2001) and elsewhere (eg Chen \& $\mathrm{Wu}, 2001$ ). However the findings regarding price are inconsistent with earlier research (eg Conrad, 1989, DeTemple \& Jorian, 1990), and the results for volume effects are inconsistent with all previous research (eg Long, Schniski \& Officer, 1994). This section discusses the empirical findings, compares and contrasts results with previous research, and analyses how the findings fit within the theoretical frameworks of complete markets, diminishing short-sales constraints and improved information environment.

Price was tested using MacKinley (1997) abnormal return methodology, using both a mean reversion model and a market adjusted model. Generally the present study finds significantly negative abnormal price around the introduction date of most of the warrant types. These findings are not consistent with early research into option introduction by Conrad (1989), DeTemple \& Jorian (1990) and Haddad \& Vorrheis (1991) who find significant positive impacts. However, they support recent research including Mayhew \& Mihov (2000) and Danielson \& Sorescu (2001), who found negative abnormal returns.

The findings of significant negative cumulative abnormal returns (CARS) around the introduction of call warrants, put warrants, COS warrants, PIE warrants and HOTS warrants are not adequately explained by the complete markets theory. This theory predicts that the differential pay-offs improve investor preference sets, thus resulting in higher equilibrium prices. The predictions of the diminishing short-sale restrictions theory are supported by the findings of this study. The purchase of puts by investors with negative outlooks, and the sale of call warrants will create negative price pressures to maintain arbitrage free pricing equilibrium in each security. As large institutions the issuers are in position to short-sale the underlying security with fewest costs and restrictions, improving the transactional efficiency of the market, consistent with Figlewiski \& Webb (1993).

Rational expectations suggest issuers only write the warrants under the expectation of making a profit. The issuer can generate profits using warrants in several ways. One way of generating profit is to write the warrant with an expectation of the stock price decreasing - i.e. taking a speculative position. The warrant can then be re-purchased at the lower price, resulting in a profit to the issuer. The negative price impacts found for call warrants, COS warrants and HOTS warrants may be a reflection of the issuer having a superior information set, or even a 
market perception that the issuer has a superior information set about the underlying security. However, such actions are speculative, with the issuer predicting a negative price movement in the near term. The conservative nature of the issuer (eg high credit rating banking entities) would preclude such outright speculation using leveraged products. The other possible avenues for profit for the issuer are to offset their position by hedging their exposure through position in another security using their market maker benefits (i.e. the bid-ask spread) to create arbitrage profits.

This signalling hypothesis is a new facet of the improved information environment theorem. However, our results do not conclusively confirm the existence of such a superior information signal. The signalling explanation does not hold true for the results of generally no abnormal returns for barrier calls, capped calls, instalment warrants. If the issuer is writing their position based on superior information set, then the signal should give rise to negative abnormal returns (again, the issuer profits when the stock price falls). The non-significant findings may simply reflect that the market for these products is too small to have a significant price effect on the underlying security. However, barrier calls and capped calls represent lower risk for the issuer (see Appendix A), therefore they may only be written when the issuer is quite uncertain about the future direction of the stock price, which is still consistent with a signalling hypothesis.

As such, the signalling hypothesis will require further testing, with information regarding how the warrant issuer hedges their position able to give a clearer idea on the validity of the hypothesis. Overall, while each warrant offers different risk/return pay-off patterns, results indicate that the complete markets effect does not dominate the returns to the underlying stock around introduction date, with the significant negative abnormal returns indicating a diminishing short-sales restrictions effect or an improved information environment effect. Our findings are a clear rejection of the null hypothesis of no abnormal price effects around the introduction date of most of the warrant types.

Volume was tested with both a t-test for change in mean and a dummy variable regression which tested for a time-series trend in the volume and a structural break around the warrant introduction date. Initial $t$-tests for a change in mean volume found significantly increased average volume between the pre- and post- listing periods. This result, and the methodology used, is largely consistent with previous empirical findings, such as Long, Schinski and Officer (1994) and Ho and Liu (1995). However, improving the methodology by considering that volume may be 
upward trending generates contrasting results, finding significant decreases in trading volume. To the authors' knowledge, this is the first research in the area that has found such a result. While no other research has used a dummy variable regression technique with a time-series variable to detect the trend, the findings show that every single group of companies tested had highly significant upward trends in volume. Using a t-test for change in mean or a regression without the time-series trend will result in significant increases in volume are caused by the underlying trend rather than the actual event. The main finding of a difference in results between using such methodology compared to a t-test indicates that conclusions drawn by earlier research which uses such empirical techniques may not be as conclusive as first thought.

While the complete markets hypothesis predicts an increase in volume due to more investor participation, this is shown here not to be the case with warrants in the Australian market. The diminishing short-sale restrictions hypothesis has no prediction for a change in volume. The improved information environment hypothesis suggests two opposite effects. Increased profile and analyst following (which is not tested in this paper) predict an increase in volume, while the informed trading aspect predicts insiders and speculators shift their activities, using the high leveraged derivative products as substitutes for investment in the underlying securities. This shifting between from the stock market to the warrant market is referred to here as the substitution theory, where investors are substituting their actions in the stock market with actions in the warrant market to access the leverage and other benefits of warrants.

It was found that call warrant introduction significantly increased the trading volume in the underlying security, using both a t-test for change in pre-listing mean to post-listing mean volume and a dummy variable regression that considered the time-series trend. This finding is consistent with the complete markets hypothesis predictions and the previous research, such as Long, Schinksi \& Officer (1994).

Findings of decreased volume (after accounting for the upward trend) after barrier call, capped call and COS warrants are introduced are consistent with the substitution theory. These products are speculative investments; therefore there is an incentive for speculators and traders with superior information sets to shift activities away from the underlying security to trade these products.

Findings of no change in volume for instalment and PIE's warrants show that there seems to be no substitution effects, or if there is they are cancelled by other effects (such as the complete 
markets effect). These products are less speculative and longer term than other classes of warrants, thus little incentive for speculators to shift activities. However, long term investors may liquidate holdings in the underlying to purchase instalments or PIES to gain longer term leveraged exposure to movements in the underlying asset. Total volume effects of no significant change do not add credence to this theory.

HOTS warrants were the only warrants to still have a positive impact on the underlying securities trading volume, after adjusting for the trend. This indicates that a complete markets effect is dominant, inducing investors to the underlying stock due to differential risk/return payoffs possible with combining positions in the underlying with the HOTS.

Introducing put warrants results in a decrease in underlying volume, after considering the underlying trend. This again would appear that traders are using the put warrants as a vehicle for trading rather than the underlying security. This is an interesting finding, as it indicates a substitution for trading the underlying, while the diminishing short-sales restrictions theorem suggests that only (mainly) traders with positive outlooks are in the stock market, while put introduction will induce new traders with negative outlooks, rather than cause current traders to switch positions. Current theoretical frameworks cannot adequately explain this finding.

In summary, introduction of a call warrant significantly increases the volume in the underlying security, even after considering the underlying upward trend. This finding is consistent with theoretical frameworks and previous findings. However, other warrant introduction results in a significant decrease in the trading volume of the underlying security, which is explained here using a substitution hypothesis. This result is based on the assumption that the predictive model of including a time-series trend is an appropriate model to estimate trading volume. As the methodology is different to that used in previous research, and previous research findings are in contrast to the findings in this research, it indicates that the evidence found in previous research of increased trading volume may not be as conclusive as first thought. It is evident that more research is required to examine the impact of derivative introduction on the underlying securities trading volume.

Variance was found to decrease significantly subsequent to capped call and increase significantly subsequent to PIE warrant introduction. However, after considering GARCH/ARCH effects, only PIE warrant introduction still caused a significant change in the underlying securities 
volatility. The other types of warrants do not seem to have a significant impact of the volatility of the underlying securities.

These results are consistent with findings Long, Schinski and Officer (1994), however they are in contrast to most of the other research (see Table 2.3). All three theoretical frameworks indicate a decrease in volatility, therefore do not adequately explain the findings presented here. Other than PIE warrants, which have quite a small sample size, our findings are conclusive that warrant introduction does not destabilising the underlying security.

Beta was tested using a dummy variable regression that tested for both a structural break and a change in the slope of the correlation. Such tests found that the seemingly very large average percentage changes in beta did not always indicate a significant change in the betas of the underlying stocks.

Previous research (eg Conrad, 1989) and Long, Schinski \& Officer, 1994) has generally found no or very small effects on the beta between the pre-derivative and post-derivative periods. Results in this paper show similar findings, with introduction of put warrants, capped call warrants, COS warrants, HOTS warrants, PIE warrants and call warrants all resulting in no significant changes in beta. It was found that barrier call warrant and instalment experience increased beta in the post-listing period, however only at the $10 \%$ level of significance. It should be noted that the dummy variable regressions were tested using both simple beta's and Scholes Williams Beta with no difference to the results or significance of the results.

\section{CONCLUSION}

Utilising an abnormal returns approach supported by dummy variable regression, this research reject the null hypothesis that warrant listing causes no impact on the underlying security. The findings of generally negative cumulative abnormal returns around the issue date are consistent with the most recent research in the field (eg Danielsen \& Sorescu, 2001). Previous research explains their results through the diminishing short-sales restrictions hypothesis, which partially applies here. The improved information environment hypothesis is used as an additional explanation of the results, where the issuing investment bank is a sophisticated entity with insider or superior information sets so that their actions in the warrants market convey an information signal to other market participants. 
However, not all results are consistent with improved information environment/signalling theory, with put warrant introduction also showing negative abnormal returns, when the theory suggests a positive signal, and no abnormal returns experienced for some of the warrant classes. The effects of the puts are attributed to the diminishing short sale restrictions hypothesis, as they are unique amongst the warrant products in that they benefit the purchaser as the stock price decreases. Other warrants results of non-significance may reflect that they are too small to influence the underlying stock prices.

The most interesting results were the findings regarding volume effects. Previously published research had found increases in average trading volume after the derivative product was introduce. While call warrant introduction conclusively results in higher trading volume in the underlying security, further testing shows mixed results for other warrant types. Expanding on previous methodology by adjusting for the underlying upward trend in volume results in findings of warrant introduction generally causes a decrease in the trading volume. This is attributed to substitution effects - investors/traders are replacing their activities in the stock market to activities in the warrants market, so as to access the increased leverage and other advantageous features of the warrants.

Results regarding risk show that standard measures of risk, being variance and beta, are generally unchanged between the pre-warrant and post-warrant periods.

In results not presented here it was found that call warrants and put warrants have no significant impacts when a call or put option is already exchange traded show that issuance of such products on companies with options is redundant and does not achieve any real economic gains or efficiencies. This is also an important finding regarding the future development of derivative warrant markets, either in Australia or elsewhere, as their would seem to be little point issuing new products that are essentially the same as already available products. However, since it appears that stocks with other derivative warrant products generally have either informational efficiencies or help complete the market with differential pay-off patterns, creating similar exchange traded products in other markets may be beneficial for participants in those markets.

Recent research, such as Faff \& Hiller (2003) and Danielsen \& Sorescu (2001) have found differing empirical results regarding the impact of option listing on the underlying security, when compared to early research, such as Conrad (1989) and DeTemple \& Jorian (1990). This 
research has also found differing results, especially regarding volume impacts, which previously had unanimously been found to be positive. Due to the changing results over time, the early theoretical models used to explain the impact of derivative listing no longer accurately describe all the effects found. Presented in this paper are two alternative possible explanations, where price effects are a result of a signalling effect by the writer of the warrant and where decreased volume is a result of a substitution effect towards warrants and away from the underlying stock. Future research into this field requires new theoretical frameworks that can fully explain empirical findings. Regarding volume, the methodology applied in this paper, previously lacking in many papers, suggests that previous findings of increased volume may need to be reexamined and/or a more powerful model for testing volume change needs to be developed.

Using relatively small sample sizes creates the potential for outlier influence, especially regarding capped call warrant listing where only seven companies were tested. However, event study methodology is acceptable for testing a single company/stock, so the small sample sizes are not considered a major issue.

In general the results show that introducing a derivative warrant product into the Australian financial markets has a level of impact, either through an improved price mechanism, improved information environment or substitution effects. However, similar to recent research findings into option listing effects, current theoretical frameworks fail to fully explain all the effects derivative warrant introduction has on the underlying security. This research used empirical techniques to test the effects, and contributes to the theoretical frameworks with expansions and consolidation regarding the improved information environment hypothesis, which has previously been quite fragmented. The results of this research; being a negative price impact, decreased volume and no change in risk; and other recent empirical findings such as Mayhew \& Mihov (2000) or Faff \& Hillier (2003), indicate a requirement for further development of the theoretical frameworks, which is left to future research efforts. 


\section{REFERENCES}

Arditti, F. \& John, K. (1980), "Spanning the State Space with Options," Journal of Financial and Quantitative Analysis, Vol. 15, pp. 1-9.

Armitage, S. (1995), "Event Study Methods And Evidence On Their Performance," Journal of Economic Surveys, Vol. 9, Iss. 1, pp. 25-52.

Australia Stock Exchange FactFile 2002 and 2003.

Ball, R. \& Brown, P. (1968), “An Empirical Evaluation Of Accounting Income Numbers,” Journal of Accounting Research, Vol. 6, Iss. 2, pp. 159-178.

Becchetti, L. \& Caggese, A. (2000), "Effects Of Index Option Introduction On Stock Index Volatility: A Procedure For Empirical Testing Based On SSC-GARCH Models," Applied Financial Economics, Vol. 10, Iss. 3, pp. 323-341.

Black, F. (1993), “Beta and Returns”, Journal of Portfolio Management, Vol. 20, pp. 8-18 Black, F. \& Scholes, M, (1973). “The Pricing of Options and Corporate Liabilities,” Journal of Political Economy, Vol. 81, pp. 637-659.

Bollerslev, T. (1986), "Generalized Autoregressive Conditional Heteroskedasticity," Journal of Econometrics, Vol. 3, Iss. 3, pp. 307-328.

Brailsford, T. \& Heaney, R. (1997), Investments: Concepts and Applications in Australia, Harcourt Australia, Marrickville.

Branch, B. \& Finnerty, J. E. (1981), “The Impact of Option Listing on the Price and Volume of the Underlying Stock.” Financial Review, Vol. 16, pp. 1-15.

Broughton, J. B. \& Smith, D. M. (1997), “Option Listing Effects And The Role Of Confounding Effects," Quarterly Journal of Business and Economics, Vol. 36, Iss. 4, pp. 15-23.

Brown, S. J. \& Warner J.B. (1985), “Using Daily Stock Returns: The Case of Event Studies” Journal of Financial Economics, Vol. 14, pp. 3-31.

Cable, J. \& Holland, K. (1999), "Modelling Normal Returns In Event Studies: A ModelSelection Approach And Pilot Study," European Journal of Finance, Vol. 5, Iss. 4, pp. 331-341 Chen, K. C. \& Wu, L. (2000), "Introduction And Expiration Effects Of Derivative Equity Warrants In Hong Kong,” International Review of Financial Analysis, Vol. 9, Iss. 1, pp. 37-52. Conrad, J. (1989), “The Price Effect of Option Introduction.” Journal of Finance, Vol. 44, pp. 487-499. 
Damodaran, A \& Lim, J. (1991), "The Effects of Option Listing on the Underlying Stocks' Return Processes,” Journal of Banking and Finance, Vol. 15, pp. 647-664.

Damodaran, A \& Lim, J. (1991), "Put Listing, Short-Sales and Return Processes,” Working Paper Series, Stern School of Business

Damodaran, A \& Subrahmanyam, M. G. (1992), "The Effects of Derivative Securities on the Markets for the Underlying Assets in the United States: A Survey," Financial Markets, Institutions \& Instruments, Vol. 1, Iss. 5, pp. 1-22.

Danielsen, B.R \& Sorescu S.M. (2003), "Why Do Option Introductions Depress Stock Prices? A Study of Diminishing Short-Sale Constraints," Journal of Financial and Quantitative Analysis, Forthcoming

Detemple J. \& Jorion, P. (1990), “Option Listing and Stock Returns,” Journal of Banking and Finance, Vol. 14, pp. 781-802.

Detemple, J. \& Selden, L. (1991), “A General Equilibrium Analysis of Option and Stock Market Interactions," International Economic Review, Vol. 32, pp. 279-303.

Diamond, D. W. \& Verrecchia, R. E. (1987), "Constraints on Short-Selling and Asset Price Adjustment to Private Information,” Journal of Financial Economics, Vol. 18, pp. 277-312." Dimson, E. (1979), "Risk Measurement When Shares Are Subject To Infrequent Trading," Journal of Financial Economics, Vol. 7, Iss. 2, pp. 197-226.

Draper, P., Mak, B. S. C., \& Tang, G. Y. N. (2001), “The Derivative Warrant Market In Hong Kong: Relationships With Underlying Assets," Journal of Derivatives, Vol. 8, Iss. 4, pp. 72-83.

Dyckman, T., Philbrick, D. \& Stephan, J. (1984), “A Comparison Of Event Study Methodologies Using Daily Stock Returns: A Simulation Approach,” Journal of Accounting Research, Vol. 22, pp. 1-30.

Elfkani, M. \& Chuadhury, S. (1997), "Listing of Put Options: Is There any Volatility Effect?," Review of Financial Economics, Vol. 6, Iss. 1, pp. 57-76

Faff, R. W. \& Hillier, D. J. (2003), “Complete Markets, Informed Trading and Equity Option Introductions" (February 28, 2003). EFA 2003 Annual Conference Paper No. 507.

Fama, E. F. (1991), “Efficient Capital Markets: II,” Journal of Finance, Vol. 46, Iss. 5, pp. 1575 1618.

Figlewski, S. \& Webb, G. P. (1993), “Options, Short Sales, and Market Completeness,” Journal of Finance, Vol. 48, pp. 761-777." 
Freund, S., McCann, D. \& Webb, G. P. (1994), “A Regression Analysis of the Effects of Option Introduction on Stock Variances", Journal of Derivatives, Vol. 1, pp. 25-38.

Greenspan, A. (1999), "Financial Derivatives and the Risks they Entail," (March 19, 1999). Speech to Futures Industry Association, Boca Raton Florida.

Grossman, S. J. (1988), “An Analysis of the Implications for Stock and Futures Price Volatility of Program Trading and Dynamic Hedging Strategies," Journal of Business, Vol. 61, pp. 275298.

Haddad, M. M. \& Voorheis, F. L. (1991), “Initial Option Trading And Security Risk And Return,” Journal of Business Finance and Accounting, Vol. 18, Iss. 6, pp. 903-914.

Ho, L. C. J. \& Liu, C. S. (1997), “A Reexamination Of Price Behaviour Surrounding Option Introduction," Quarterly Journal of Business and Economics, Vol. 36, Iss. 4, pp. 39-50.

Ho, L. C. J., Hassel, J. M. \& Swidler, S. (1995) “An Empirical Examination Of The Dispersion And Accuracy Of Analyst Forecasts Surrounding Option Listing," Review of Financial Economics, Vol. 4, Iss. 2, pp. 171-185.

IIkenberry, D., Lakonishok, J. \& Vermaelen, T. (1995), “Market Underreaction To Open Market Share Repurchases,” Journal of Financial Economics, Vol. 39, Iss. 2/3, pp. 181208.

Kim, W. S. \& Young, S. M. (1991), “The Effect Of Traded Option Introduction On Shareholder Wealth,” Journal of Financial Research, Vol. 14, Iss. 2, pp. 141-152.

Kumar, R., Sarin, A. \& Shastri, K. (1998), “The Impact of Options Trading on the Market Quality of the Underlying Security: An Empirical Analysis,” Journal of Finance, Vol. 53, pp. 717-732."

Lang, M. H., Lins, K. V. \& Miller, D. P. (2002), "ADRs, Analysts, and Accuracy: Does Cross Listing in the U.S. Improve a Firm's Information Environment and Increase Market Value?," Working Paper Series, Indiana University

Long, M. D., Schinski, M. D. \& Officer, D. T. (1994), “The Impact Of Option Listing On The Price Volatility And Trading Volume Of Underlying OTC Stocks," Journal of Economics and Finance, Vol. 18, Iss. 1, pp. 89-100.

McKenzie, M. D., Brailsford, T. J. \& Faff, R. F. (2001), "New Insights Into The Impact Of The Introduction Of Futures Trading On Stock Price Volatility,” Journal of Futures Markets, Vol. 21, Iss. 3, pp. 237-255. 
Mihov, V. T. \& Mayhew, S. J. (2000) “Another Look at Option Listing Effects” Working Paper Series, Texas Christian University, Jan.

Miller, E.M. (1977), "Risk, Uncertainty, and Divergence of Opinion," Journal of Finance, Vol. 32, pp. 1151-1168

Neindorf, B. D. \& Peterson D. R. "The Cross-Sectional Effects Of Option Listing On Firm Stock Return Variances,” Journal of Financial Research, Vol. 19, Iss. 4, pp. 515-539.

Partnoy, F. (2001), “Some Policy Implications of Single-Stock Futures,” Working Paper Series, University of San Diego Law \& Economics, No. 10.

Ross, S. (1977), “Options and Efficiency,” Quarterly Journal of Economics, Vol. 90, pp. 75-89. Saliba, A. J. (2002), The Options Workbook: Fundamental Spread Concepts and Strategies for Investors and Traders, Dearborn, New York

Schinski, M. D. \& Long, M. D. (1995), “The Wealth Effects Of Liquidity Gains From Option Listing," Research in Finance, Vol. 13, Iss. 1, pp. 203-217.

Scholes, M \& Williams, J. (1977), "Estimating Betas from Non-synchronous Data," Journal of Financial Economics, Vol. 5, Iss. 3, pp. 309-327.

Singh, R. A. (1995), "Response Of Financial Markets To Announcements Of The Australian Current Account Balance," Accounting and Finance, Vol. 35, Iss. 2, pp. 155-174.

Skinner, D. J. (1989), “Options Markets and Stock Return Volatility”, Journal of Financial Economics, Vol. 23, pp. 61-78.

Sorescu, S. (2000), “The Effect of Options on Stock Prices: 1973-1995” Journal of Finance, Vol. 55, pp. 487-514.

St. Pierre, E. F. (1998) “The Impact Of Option Introduction On The Conditional Return Distribution Of Underlying Securities,” Financial Review, Vol. 33, Iss. 1, pp.105-118. Warde, Ibrahim, (1998), “LTCM, a Hedge Fund above Suspicion”, Le Monde Diplomatique English Internet Edition, April

Watt, W. H., Yadav, P. K. \& Draper, P. (1992), “The Impact Of Option Listing On Underlying Stock Returns: The UK Evidence," Journal of Business Finance and Accounting, Vol. 19, Iss. 4, pp. 485-504.

Whiteside, M. M., Dukes, W. P. \& Dunne, P. M. (1983), "Short Term Impact Of Option Trading On Underlying Securities,” Journal of Financial Research, Vol. 6, Iss. 4, pp. 313-321. 
Page 62 of 62 